\title{
Elucidating real-world vehicle emission factors from mobile measurements over a large metropolitan region: a focus on isocyanic acid, hydrogen cyanide, and black carbon
}

\author{
Sumi N. Wren ${ }^{1}$, John Liggio ${ }^{1}$, Yuemei Han ${ }^{1}$, Katherine Hayden ${ }^{1}$, Gang Lu ${ }^{1}$, Cris M. Mihele ${ }^{1}$, \\ Richard L. Mittermeier ${ }^{1}$, Craig Stroud ${ }^{1}$, Jeremy J. B. Wentzell ${ }^{1}$, and Jeffrey R. Brook ${ }^{1, a}$ \\ ${ }^{1}$ Air Quality Process Research Section, Air Quality Research Division, Environment and Climate Change Canada, \\ 4905 Dufferin St., Toronto, ON, M3H 5T4, Canada \\ ${ }^{a}$ currently at: Dalla Lana School of Public Health, Department of Chemical Engineering and Applied Chemistry, \\ University of Toronto, 223 College St., Toronto, ON, M5T 1R4, Canada
}

Correspondence: Sumi N.Wren (sumi.wren@gmail.com) and Jeffrey R. Brook (jeff.brook@utoronto.ca)

Received: 27 April 2018 - Discussion started: 18 May 2018

Revised: 21 September 2018 - Accepted: 29 October 2018 - Published: 30 November 2018

\begin{abstract}
A mobile laboratory equipped with state-of-the-art gaseous and particulate instrumentation was deployed across the Greater Toronto Area (GTA) during two seasons. A high-resolution time-of-flight chemical ionization mass spectrometer (HR-TOF-CIMS) measured isocyanic acid (HNCO) and hydrogen cyanide ( $\mathrm{HCN})$, and a high-sensitivity laserinduced incandescence (HS-LII) instrument measured black carbon (BC). Results indicate that on-road vehicles are a clear source of $\mathrm{HNCO}$ and $\mathrm{HCN}$ and that their impact is more pronounced in the winter, when influences from biomass burning (BB) and secondary photochemistry are weakest. Plume-based and time-based algorithms were developed to calculate fleet-average vehicle emission factors (EFs); the algorithms were found to yield comparable results, depending on the pollutant identity. With respect to literature EFs for benzene, toluene, $\mathrm{C} 2$ benzene (sum of $m-, p$-, and $o$-xylenes and ethylbenzene), nitrogen oxides, particle number concentration (PN), and black carbon, the calculated EFs were characteristic of a relatively clean vehicle fleet dominated by light-duty vehicles (LDV). Our fleet-average EF for BC (median: $25 \mathrm{mg} \mathrm{kg}_{\text {fuel }}^{-1}$; interquartile range, IQR: $10-76 \mathrm{mg} \mathrm{kg}_{\text {fuel }}^{-1}$ ) suggests that overall vehicular emissions of $\mathrm{BC}$ have decreased over time. However, the distribution of EFs indicates that a small proportion of high-emitters continue to contribute disproportionately to total $\mathrm{BC}$ emissions. We report the first fleet-average EF for HNCO (median: $2.3 \mathrm{mg} \mathrm{kg}_{\text {fuel }}^{-1}$, IQR: $1.4-4.2 \mathrm{mg} \mathrm{kg}_{\text {fuel }}^{-1}$ ) and $\mathrm{HCN}$ (median: $0.52 \mathrm{mg} \mathrm{kg}_{\text {fuel }}^{-1}$,
\end{abstract}

IQR: $0.32-0.88 \mathrm{mg} \mathrm{kg}_{\text {fuel }}^{-1}$ ). The distribution of the estimated EFs provides insight into the real-world variability of $\mathrm{HNCO}$ and $\mathrm{HCN}$ emissions and constrains the wide range of literature EFs obtained from prior dynamometer studies. The impact of vehicle emissions on urban HNCO levels can be expected to be further enhanced if secondary HNCO formation from vehicle exhaust is considered.

\section{Introduction}

In urban areas, traffic-related air pollution (TRAP) is associated with adverse impacts on human health, air quality, climate change, and the environment (Pope and Dockery, 2006; Grahame et al., 2014; HEI Panel on the Health Effects of Traffic-Related Air Pollution, 2010). Studies of TRAP, from both the emission and exposure perspective, have often focused on criteria air pollutants such as nitrogen oxides $\left(\mathrm{NO}_{x}\right)$, carbon monoxide $(\mathrm{CO})$, and particulate matter (PM) (Jerrett et al., 2009; Beckerman et al., 2008). However, it is not established to what extent these species are solely responsible for negative outcomes associated with TRAP or to what degree they act in tandem with, or as proxies for, other compounds in the pollutant mixture (Brook et al., 2007; Mauderly and Samet, 2009; Dominici et al., 2010). That is, $\mathrm{NO}_{\mathrm{x}}$ could be an indicator for other pollutants originating from vehicular combustion, including volatile organic compounds (VOCs) and particulate species (Brook et 
al., 2007). For that reason, it is imperative that other components of TRAP are characterized, including the near-road exposures and vehicle emission factors (EFs) of air toxics. In the current study we focus on vehicle emissions of black carbon (BC), isocyanic acid ( $\mathrm{HNCO}$ ), and hydrogen cyanide $(\mathrm{HCN})$.

Although particulate mass is often used as an indicator for health risks associated with combustion, it has been suggested that black carbon may be a more effective metric (Janssen et al., 2011; Grahame et al., 2014). Black carbon particles pose a significant health risk due to their chemical stability, large surface area, and small mode diameter, with the smallest (i.e., ultrafine) BC particles able to penetrate the lung lining and enter the blood stream (Highwood and Kinnersley, 2006). However, it is not established whether it is the compounds associated with BC (such as particle-bound polycyclic aromatic hydrocarbons) or the $\mathrm{BC}$ itself that are responsible for negative effects (Janssen et al., 2011). The dominant sources of $B C$ are combustion related and include open biomass burning (BB) and residential, industrial, and transportation-related fossil-fuel burning. Anthropogenic BC emissions have been closely linked to vehicle emissions, particularly those associated with heavy-duty diesel vehicles (HDDVs) (Bahadur et al., 2011; Ban-Weiss et al., 2008). Although, BC emissions from light-duty gasoline vehicles (LDGVs) have been considered to be quite low by comparison, their exact magnitude is not well constrained, with recent studies suggesting that they may both be underestimated (Liggio et al., 2012; Krecl et al., 2017) and overestimated (Wang et al., 2016). Furthermore, improvements in emissions control technologies have seen HDDV BC emissions decrease significantly (Dallmann et al., 2012; Krecl et al., 2017). As a result, the relative importance of gasoline versus diesel engines as sources of BC is not well established, leading to uncertainties in present-day on-road inventories (Liggio et al., 2012; Krecl et al., 2017). Given the rapid pace of change of fuel injection and emission control technologies, establishing current, fleet-average $\mathrm{BC}$ emission factors is important for evaluating bottom-up inventories, which are necessary from both a health and air quality and climate perspective (Bond et al., 2013).

Only recently has it been suggested that HNCO (Wentzell et al., 2013; Brady et al., 2014; Link et al., 2016; SuarezBertoa and Astorga, 2016; Jathar et al., 2017) and HCN (Crounse et al., 2009; Moussa et al., 2016; Harvey et al., 1983) can be emitted by on- and off-road vehicles. Isocyanic acid is a highly toxic gaseous acid which dissociates at physiological $\mathrm{pH}$ to form cyanate anions $\left(\mathrm{NCO}^{-}\right)$ which in turn participate in damaging carbamylation reactions, thereby leading to adverse health outcomes such as cataracts, atherosclerosis, rheumatoid arthritis, cardiovascular disease, and renal failure (Roberts et al., 2011, and references therein). Roberts et al. (2011) used the physical properties of HNCO to estimate that ambient mixing ratios as low as 1 ppbv could be harmful to humans (Wang et al., 2007).
Similar to HNCO, hydrogen cyanide is a highly toxic gas with known negative effects on human health due to its interference in aerobic metabolism (Logue et al., 2010; Barillo, 2009; US EPA, 2010).

Historically, biomass burning was considered to be the dominant global source of both HNCO (Veres et al., 2010; Roberts et al., 2011; Young et al., 2012) and HCN (Li et al., 2000, 2003, 2009; Shim et al., 2007). Global HCN (Li et al., 2003) and HNCO (Young et al., 2012) models have hitherto considered vehicle sources of these compounds to be negligible. As such, past measurements of these species have focussed on regions heavily influenced by biomass burning or, in the case of HCN, on the upper troposphere or total tropospheric column. Although the advent of chemical ionization mass spectrometers has allowed for real-time measurements of atmospherically relevant concentrations of these species (Roberts et al., 2011; Veres et al., 2008; Woodward-Massey et al., 2014; Le Breton et al., 2013; Knighton et al., 2009), there remain relatively few measurements of ambient $\mathrm{HNCO}$ (Roberts et al., 2011, 2014; Wentzell et al., 2013; Zhao et al., 2014; Woodward-Massey et al., 2014; Sarkar et al., 2016; Chandra and Sinha, 2016; Kumar et al., 2018). Measurements of ground-level HCN in both rural and urban environments with minimal BB influence are more limited (Ambrose et al., 2010). However, given the recent studies suggesting that $\mathrm{HCN}$ and $\mathrm{HNCO}$ emissions from vehicles could be significant, especially at a local scale, a better understanding of on-road emissions of these species is necessary. Moreover, ambient measurements are suggestive of a secondary source of HNCO (Roberts et al., 2011, 2014; Wentzell et al., 2013; Zhao et al., 2014; Sarkar et al., 2016; Kumar et al., 2018) formed photochemically by the photooxidation of precursors such as alkyl amines and amides (Borduas et al., 2013, 2015; Sarkar et al., 2016). Recent studies (Jathar et al., 2017; Link et al., 2016) show that diesel engine exhaust itself contains precursors leading to enhanced photochemical production of $\mathrm{HNCO}$, even further underscoring the need to quantify vehicular emissions of HNCO in dense, urban environments.

Existing literature values for $\mathrm{HNCO}$ and $\mathrm{HCN}$ emission factors have been exclusively obtained from chassis or engine dynamometer studies on a limited number of engines/vehicles. While the strength of dynamometer studies is control over factors such as vehicle age, fuel composition, type of after-treatment technologies, temperature, and driving mode, they have limitations with respect to yielding representative emission factors, for the precise reason that mobile emissions have been shown to be sensitive to such factors (Franco et al., 2013). It is important that the accuracy of emission inventories derived from dynamometer results is verified against in-use vehicle emissions (Parrish, 2006), since emission inventories are often used to constrain regional budgets and exposure estimates for traffic-related air pollutants. This is particularly relevant for HNCO and $\mathrm{HCN}$, where there are large discrepancies in reported emission factors. Although real-world EF measurements can suf- 
fer from their own shortcomings (namely lower precision and repeatability), they are essential in identifying gaps and providing insight into actual emission behavior of on-road vehicles (Franco et al., 2013).

In the present study, we deploy a mobile laboratory over a large metropolitan region in two seasons, with the goal of characterizing near-road exposure and fleet-average emission factors for black carbon, $\mathrm{HNCO}$, and $\mathrm{HCN}$. These species are discussed alongside benzene, a regulated traffic pollutant of interest due to its carcinogenic nature, and whose behavior has been more thoroughly characterized. The focus in this paper is on the development of plume-based and time-based methodologies to calculate fuel-based vehicle emission factors. We assess their performance against each other and in comparison to available literature EFs for a wide range of pollutants: benzene, toluene, $\mathrm{C} 2$ benzenes (sum of $m-, p$-, and $o$-xylenes and ethylbenzene $), \mathrm{NO}_{x}\left(=\mathrm{NO}+\mathrm{NO}_{2}\right)$, particle number concentration (PN), and black carbon. We report, to our knowledge, the first real-world, fleet-average HNCO and $\mathrm{HCN}$ vehicle emission factors and use them to help assess dynamometer results relative to real-world conditions. Finally, the estimated fleet-average emission factors are scaled up to determine the relative importance of vehicle emissions of $\mathrm{HNCO}$ and $\mathrm{HCN}$.

\section{Materials and methods}

\subsection{Mobile laboratory measurements - CRUISER}

\subsubsection{Overview of mobile measurements}

Air quality and meteorological measurements were made from Environment and Climate Change Canada's mobile laboratory: Canadian Regional and Urban Investigation System for Environmental Research (CRUISER) (Levy et al., 2014; Government of Canada, 2018). CRUISER was deployed during two seasons over the Greater Toronto Area (GTA), a metropolitan area encompassing the city of Toronto and four regional municipalities with a population of over 6 million. The summer campaign took place over 9 days in July 2015 $(15,16,17,20,21,22,23,27$, and 28 July) as part of the Environment Canada Pan and Parapan American Science Showcase (ECPASS) (Joe et al., 2018). The winter campaign took place over 8 days in January $2016(11,13,14$, $15,18,19,20$, and 21 January) as part of a health exposure mapping study. Driving took place on weekdays only, with the majority of measurements occurring between 09:00 and 17:00 LT (local time). Driving routes were chosen to pass along highways, major roadways, and local streets, and to visit residential, commercial, and industrial areas; the driving routes for the summer and winter campaign are shown in Fig. S1 in the Supplement. In 2016 the Ontario vehicle fleet was composed of approx. $97 \%$ light-duty vehicles (LDVs; vehicles $<4500 \mathrm{~kg}$ and motorcycles/mopeds) and
$4 \%$ heavy-duty vehicles (HDVs; for this paper, the HDV category includes both medium-duty vehicles $4500-14999 \mathrm{~kg}$ and heavy-duty trucks $>15000 \mathrm{~kg}$, as well as buses) (Statistics Canada, 2016); the composition of the GTA vehicle fleet is assumed to be similar.

Several gas-phase and particle-phase instruments were housed on-board CRUISER as listed in Table 1. Carbon dioxide $\left(\mathrm{CO}_{2}\right)$ was measured with $2 \mathrm{~s}$ time resolution by cavityenhanced laser absorption spectroscopy (PICARRO). All gas-phase instruments sampled from a common inlet with the exception of the high-resolution time-of-flight chemical ionization mass spectrometer (HR-TOF-CIMS) which sampled off a dedicated inlet located on the roof of CRUISER towards the rear right side. The common gas-phase inlet was located $3.6 \mathrm{~m}$ a.g.l. and oriented near the front left side. Ambient air was sampled through a $2 \mathrm{~m}$ long PFA tube with $0.61 \mathrm{~cm} \mathrm{ID}$ followed by a $30 \mathrm{~cm}$ long PFA tube with $0.52 \mathrm{~cm}$ ID at a rate of 13.6 SLPM (residence time $\sim 0.25 \mathrm{~s}$ ); inlet lines for various instruments were connected downstream of this common inlet. All particle-phase instruments sampled off a common stainless steel inlet located adjacent to the gas-phase inlet. During the winter campaign, $\mathrm{CO}_{2}$ was sampled from the same inlet as the HR-TOF-CIMS. Relative wind speed and wind direction was measured using an ultrasonic anemometer located on the roof at the front of CRUISER. Periods of potential self-sampling were identified and removed using an algorithm which is described in the Supplement. Briefly, the self-sampling algorithm identified periods of potential exhaust based on CRUISER speed, relative wind speed, and wind direction (towards inlet) and periods of suspected exhaust within these windows, based on the presence of exhaust tracers (BC, NO, fine particle counts). Periods of suspected exhaust were removed from the data.

\subsubsection{Proton-transfer-reaction time-of-flight mass spectrometry (PTR-TOF-MS)}

Volatile organic compounds were measured using a protontransfer-reaction time-of-flight mass spectrometer (PTRTOF-8000, Ionicon Analytik). The operating principles of the PTR-TOF-MS instrument have been described elsewhere (Jordan et al., 2009; Li et al., 2017); further details can be found in the Supplement. Briefly, the PTR-TOF-MS was operated with an E/N value of $140 \mathrm{Td}$. Air for analysis by the PTR-TOF-MS was sampled off the common gas-phase inlet via a $2 \mathrm{~m}$ long PFA tube with $0.52 \mathrm{~cm}$ ID at a rate of 4.4 SLPM and the instrument sampled part of this flow $(100 \mathrm{sccm})$ through a $120 \mathrm{~cm}$ insulated PEEK capillary with $0.08 \mathrm{~cm}$ ID heated to $70^{\circ} \mathrm{C}$. Mass spectra were acquired with a time resolution of $1 \mathrm{~s}$ and a resulting mass resolution of

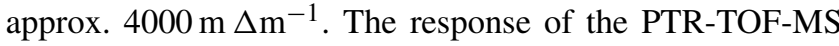
to specific VOCs was determined using a home-built zero and calibration unit and a custom VOC gas standard (Ionicon). The $2 \sigma$ detection limits differed slightly for the summer and winter campaigns and were calculated respectively to be 
110 and 155 pptv for benzene, 125 and 240 pptv for toluene, and 110 and 160 pptv for C8 benzenes. The sensitivities and detection limits are also listed in Table S1 in the Supplement.

\subsubsection{High-resolution time-of-flight chemical ionization mass spectrometer (HR-TOF-CIMS)}

HNCO and HCN were measured using a high-resolution time-of-flight chemical ionization mass spectrometer (HRTOF-CIMS, Aerodyne Research, Inc.). The design, operation, and mobile deployment of the HR-TOF-CIMS has been previously described (Veres et al., 2008; Roberts et al., 2011; Wentzell et al., 2013; Liggio et al., 2017a). Additional details can be found in the Supplement. Briefly, the HR-TOF-CIMS is a differentially pumped time-of-flight mass spectrometer configured to use iodide ion as the reagent ion (WoodwardMassey et al., 2014; Le Breton et al., 2013). Air for analysis was drawn at $\sim 22$ SLPM through a $3 \mathrm{~m}$ long heated $\left(50^{\circ} \mathrm{C}\right)$ inlet $(0.58 \mathrm{~cm} \mathrm{ID})$. The CIMS subsampled from this flow into the ion molecule reaction (IMR) region via a critical orifice at 1.7 SLPM. Mass spectra were acquired with a time resolution of $1 \mathrm{~s}$ and a resulting mass resolution of ap-

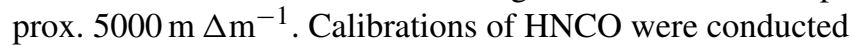
by thermally decomposing cyanuric acid at $250{ }^{\circ} \mathrm{C}$ to $\mathrm{HNCO}$ (Roberts et al., 2010) with the permeation rate quantified via Fourier-transform infrared spectroscopy (FTIR; ThermoFisher Inc.). Calibrations of $\mathrm{HCN}$ were performed by diluting a $\mathrm{HCN}$ gas standard (Air Liquide, ppmv in $\mathrm{N}_{2}$ ) in zero air. Humidity-dependent response factors for both species were derived by diluting the calibration gas flows with humidified air to a final $\mathrm{RH}$ ranging from $\sim 9 \%$ to $90 \%$, resulting in sensitivities of 0.086 and $0.1 \mathrm{ncpspptv}^{-1}$ for $\mathrm{HCN}$ and $\mathrm{HNCO}$ respectively. The $2 \sigma$ detection limits for $\mathrm{HNCO}$ and $\mathrm{HCN}$ were estimated to be $7 \mathrm{pptv}$ each for both the summer and winter campaigns.

\subsubsection{High-sensitivity laser-induced incandescence (HS-LII) for black carbon}

Black carbon measurements were made with a highsensitivity laser-induced incandescence (HS-LII) instrument (Atrium Technologies Inc., CA, USA) developed in collaboration with the National Research Council Canada (NRC). The particular instrument on CRUISER is a research-grade prototype capable of ultra-low $\mathrm{BC}$ measurements at $1 \mathrm{~s}$ resolution. Here, black carbon is operationally defined by its high thermal stability (Petzold et al., 2013). The principle of operation of this instrument, as well as its use during ambient studies, has been described elsewhere (Snelling et al., 2005; Chan et al., 2011; Liggio et al., 2012). Briefly, ambient particles within a set volume are rapidly heated by a pulsed laser beam $\left(1064 \mathrm{~nm} ; 7 \mathrm{~ns}\right.$ FWHM, $\left.200 \mathrm{~mJ} \mathrm{pulse}^{-1}\right)$ to just below the soot sublimation temperature $(\sim 4000 \mathrm{~K})$. The absolute incandescence and temperature of the $\mathrm{BC}$ particles are measured by collection optics and photomultipliers. After appro- priate calibration and analysis, these two parameters are used to determine the soot volume fraction, which is converted to a $\mathrm{BC}$ mass concentration with knowledge of the particle material density $(\rho)$ and the absorption function $\left(E_{\mathrm{m}}\right)$, both of which are well established for BC (Coderre et al., 2011; Choi et al., 1994; Wu et al., 1997). An advantage of this technique is that it determines ensemble properties for all particles within the sample volume and so does not suffer from a particle size limitation; previous studies have shown that the HS-LII can detect laboratory-generated particles $<7 \mathrm{~nm}$ in diameter (Stirn et al., 2009). As a result, a previous study found that $\mathrm{BC}$ measurements by a single-particle soot photometer (SP2), which is only sensitive to particles with a diameter $>70 \mathrm{~nm}$, are biased low relative to the HS-LII (Liggio et al., 2012). Furthermore, it has been shown that the HSLII is significantly less influenced by the presence of nonrefractory mass compared to other BC measurement methods such as photoacoustic spectrometers (Chan et al., 2011). The HS-LII was only in operation for the summer campaign.

\subsection{Calculating fleet-average emission factors from a mobile platform}

Mobile measurements (Jiang et al., 2005; Canagaratna et al., 2004; Zavala et al., 2006, 2009; Park et al., 2011; Liggio et al., 2012; Hudda et al., 2013; Jimenez et al., 2000) of individual tailpipe emissions (i.e., plumes) have proven to be an effective approach for determining fleet emission factors, with the advantage of covering a large geographical region, while measuring emissions in real time over a range of driving modes. Hence they are able to evaluate the applicability of EF measurements made at a fixed location to the entire region, providing insight into the degree of emissions variability and identifying the presence of high-emitting vehicles.

Plume-based emissions measurements can be made in two ways: a targeted approach in which individual vehicles are "chased" (Canagaratna et al., 2004; Zavala et al., 2009; Zimmerman et al., 2016) or a "catch-all" approach in which all intercepted plumes are treated as potential exhaust plumes (Jimenez et al., 2000; Jiang et al., 2005; Zavala et al., 2009; Hudda et al., 2013; Wang et al., 2015). The advantage of the catch-all approach is that a large number of plumes can be encountered, leading to improved statistics for characterizing the fleet on the road in the domain of study (Zavala et al., 2009; Wang et al., 2015). Alternatively, emission factors from mobile measurements can be determined using a time-based or road-segment-based approach in which pollutant concentrations above background are evaluated at fixed time or distance intervals (Hudda et al., 2013; Westerdahl et al., 2009; Zavala et al., 2006, 2009). Here, we calculate fleet emission factors using both a catch-all mobile plume-based approach and a time-based approach. 
Table 1. Method of detection and ambient concentration statistics for selected pollutants on CRUISER.

\begin{tabular}{|c|c|c|c|c|c|c|c|}
\hline Pollutant and units & Instrument & $N$ & $\begin{array}{r}\text { Mean } \\
(1 \sigma)\end{array}$ & Median & $\begin{array}{r}25 \text { th } \\
\text { percentile }\end{array}$ & $\begin{array}{r}75 \text { th } \\
\text { percentile }\end{array}$ & $\operatorname{Max}$ \\
\hline \multicolumn{8}{|l|}{ Summer campaign } \\
\hline $\mathrm{C}_{6} \mathrm{H}_{6} / \mathrm{pptv}$ & PTR-TOF-MS & 112156 & $293(1043)$ & 170 & 91 & 320 & 170000 \\
\hline $\mathrm{C}_{7} \mathrm{H}_{8} / \mathrm{pptv}$ & PTR-TOF-MS & 113760 & $913(3210)$ & 382 & 198 & 757 & 395525 \\
\hline $\mathrm{C}_{8} \mathrm{H}_{10} / \mathrm{pptv}$ & PTR-TOF-MS & 112156 & $605(224)$ & 237 & 123 & 468 & 191205 \\
\hline $\mathrm{NO}_{2} / \mathrm{ppbv}$ & $\mathrm{LGR}^{\mathrm{a}}$ & 99041 & $12.7(13.3)$ & 8.5 & 4.2 & 17.5 & 552 \\
\hline $\mathrm{HNCO} / \mathrm{pptv}$ & HR-TOF-CIMS & 103951 & $45.1(39.0)$ & 39.3 & 28.4 & 53.8 & 2168 \\
\hline $\mathrm{HCN} / \mathrm{pptv}$ & HR-TOF-CIMS & 103951 & $63.8(52.4)$ & 56.6 & 41.0 & 75.4 & 2429 \\
\hline $\mathrm{NO} / \mathrm{ppbv}$ & TECO $(42 \mathrm{iTL})^{\mathrm{b}}$ & 98036 & $20.9(39.7)$ & 6.2 & 2.0 & 21.2 & 998 \\
\hline $\mathrm{CO}_{2} / \mathrm{ppmv}$ & PICARRO $^{\mathrm{c}}$ & 59275 & $415(33)$ & 408 & 392 & 435 & 1893 \\
\hline $\mathrm{PN}^{\mathrm{f}} / 1000$ counts $\mathrm{cm}^{-3}$ & $\mathrm{CPC}^{\mathrm{d}}$ & 98888 & $42.0(87.4)$ & 24.7 & 15.5 & 45.6 & 9230 \\
\hline Black carbon $/ \mu \mathrm{m}^{-3}$ & HS-LII ${ }^{\mathrm{e}}$ & 106075 & $1.06(2.32)$ & 0.38 & 0.16 & 0.97 & 43.4 \\
\hline \multicolumn{8}{|l|}{ Winter campaign } \\
\hline $\mathrm{C}_{6} \mathrm{H}_{6} / \mathrm{pptv}$ & PTR-TOF-MS & 131882 & $315(294)$ & 262 & 169 & 388 & 18500 \\
\hline $\mathrm{HNCO} / \mathrm{pptv}$ & HR-TOF-CIMS & 119642 & $25.7(54.7)$ & 15.5 & 8.8 & 27.1 & 2985 \\
\hline $\mathrm{HCN} / \mathrm{pptv}$ & HR-TOF-CIMS & 119642 & $10.6(15.7)$ & 7.7 & 5.4 & 11.2 & 1579 \\
\hline $\mathrm{CO}_{2} / \mathrm{ppmv}$ & PICARRO $^{c}$ & 78683 & $439(30)$ & 408 & 419 & 449 & 1250 \\
\hline
\end{tabular}

Principles of operation: ${ }^{a}$ cavity-enhanced laser absorption spectroscopy, ${ }^{b}$ Thermo Scientific (42iTL) chemiluminescence, ${ }^{c}$ cavity ring-down spectroscopy, ${ }^{\mathrm{d}}$ light scattering, ${ }^{\mathrm{e}}$ laser-induced incandescence. ${ }^{\mathrm{f}} \mathrm{PN}$ is the ultrafine particle number counts. Statistics obtained after the self-sampling algorithm was applied to the high-time-resolution data with $N$ data points. All instruments operated at $1 \mathrm{~s}$ resolution except PICARRO ( $2 \mathrm{~s}$ ). The mean daily temperature was ca. $25^{\circ} \mathrm{C}$ during the summer campaign and ca. $-5^{\circ} \mathrm{C}$ during the winter campaign. LGR stands for Los Gatos Research.

\subsubsection{Definition of background (BKG) and local (LOCAL) concentrations}

Pollutant and $\mathrm{CO}_{2}$ time series were averaged to $2 \mathrm{~s}$ and then further smoothed using a 3-point boxcar $(5 \mathrm{~s})$. The background (BKG) was subsequently defined as the rolling second percentile over a 90 -point $(180 \mathrm{~s})$ window, with additional boxcar smoothing over the same window. Similar approaches for estimating background concentrations from mobile monitoring studies have been employed by others (Jiang et al., 2005; Jimenez et al., 2000; Hudda et al., 2013; Park et al., 2011; Bukowiecki et al., 2002; Larson et al., 2017). Since the background is calculated over a 3 min window, corresponding to approximately $2 \mathrm{~km}$ of CRUISER travel, it is assumed to be representative of a neighborhood-scale background (Larson et al., 2017). The on-road or LOCAL concentrations are defined as the background-corrected (i.e., abovebackground) mixing ratios. Figure $\mathrm{S} 2$ shows sample time series for the summer $\left(\mathrm{CO}_{2}\right.$, benzene, $\left.\mathrm{BC}, \mathrm{HNCO}, \mathrm{HCN}\right)$ and winter campaigns $\left(\mathrm{CO}_{2}\right.$, benzene, $\left.\mathrm{HNCO}, \mathrm{HCN}\right)$ and demonstrates that the LOCAL pollutant plumes frequently co-varied with increases in $\mathrm{CO}_{2}$, suggesting a combustion (i.e., vehicular) source.

\subsubsection{Plume-based emission factor determination}

An emission factor algorithm was written using Igor Pro (Wavemetrics Inc.) to identify $\mathrm{CO}_{2}$ plumes based on the first and second derivatives of the $\mathrm{CO}_{2}$ time series, simi- lar to the approach of Wang et al. (2015). The details of the algorithm can be found in the Supplement. Briefly, the first derivative of the $\mathrm{CO}_{2}$ time series was used to identify peak boundaries and locations (peak maxima). Two types of plumes were identified: single-peak plumes (SPP) and multipeak plumes (MPP). Multi-peak plumes contain one or more $\mathrm{CO}_{2}$ peaks (and include the SPP set). Plumes less than $10 \mathrm{~s}$ in duration or with an average background-corrected $\mathrm{CO}_{2}$ response of $<5 \mathrm{ppmv} \mathrm{s}^{-1}$ over the integration period were rejected as erroneous or uncaptured (Wang et al., 2015). Emission factors (EF) expressed as $\mathrm{m} \mathrm{kg}_{\text {fuel }}^{-1}$ for a given pollutant $X$ and plume $i$ were calculated using a carbon mass balance approach:

$\mathrm{EF}_{X, i}=\frac{[X]}{\left[\mathrm{CO}_{2}\right]} \times \frac{\mathrm{MW}_{X}}{F_{\mathrm{C}} \cdot \mathrm{MW}_{\mathrm{C}}} \times C_{\text {fuel }} \times 10^{3}$,

where $[X]$ and $\left[\mathrm{CO}_{2}\right]$ are the integrated amounts of LOCAL (background-corrected) $X$ and $\mathrm{CO}_{2}$ over the boundaries of plume $i$ in units of ppbv and ppmv respectively, $\mathrm{MW}_{X}$ and $\mathrm{MW}_{\mathrm{C}}$ are the molecular weights of pollutant $X$ and carbon in $\mathrm{g} \mathrm{mol}^{-1}, \mathrm{~F}_{\mathrm{C}}$ is the molar ratio of carbon in $\mathrm{CO}_{2}, C_{\text {fuel }}$ is the carbon mass fraction in the fuel in $\mathrm{kg} \mathrm{C} \mathrm{kg}_{\text {fuel }}^{-1}$, and $10^{3}$ is the necessary unit conversion factor. A value of $C_{\text {fuel }}=0.86$ was used here, which is the average of the $C_{\text {fuel }}$ for gasoline (0.85) and diesel (0.87) (Wang et al., 2015). Strictly, the denominator in Eq. (1) should contain the sum of all emitted carbon species $\left(\mathrm{CO}_{2}, \mathrm{CO}\right.$, total hydrocarbons); however, emissions of $\mathrm{CO}_{2}$ have been shown to account for $>90 \%$ of fuel consumption (Jathar et al., 2017; Yli-Tuomi et al., 
2005). Plumes associated with the highest EFs were visually inspected and in some instances were deemed to have been erroneously captured based on poor correlation between the pollutant and $\mathrm{CO}_{2}$ time series; these plumes were removed from the final dataset. Further details regarding the background calculation and their influence on calculated EFs, as well as the peak removal processes, can be found in the Supplement (Sect. S1.5).

Emission factors for benzene, toluene, $\mathrm{C} 2$ benzenes, $\mathrm{NO}$, $\mathrm{NO}_{2}, \mathrm{NO}_{x}, \mathrm{PN}$, and $\mathrm{BC}$ were obtained during the summer campaign. EFs for $\mathrm{HCN}$ and $\mathrm{HNCO}$ were obtained during the winter campaign, when the PICARRO measuring $\mathrm{CO}_{2}$ shared the same inlet as the HR-TOF-CIMS. Statistics on the number of plumes, plume duration, and number of peaks per plume can be found in Tables S2 and S3 at various stages of analysis for the summer and winter campaigns. We note that for NO, reactions with ozone can result in a low bias for NO EFs. In this study we expect the time from emission to be on the order of minutes, although exact emission times are not known. As such it is likely that the EFs for NO here represent lower limits to the true NO EFs.

\subsubsection{Time-based emission factor determination}

Emission factors were also calculated using the time-based approach, which considers the entire data set, in contrast to the plume-based approach which only considers periods of elevated $\mathrm{CO}_{2}$ as defined by peaks (Westerdahl et al., 2009). The LOCAL (background-corrected) $\mathrm{CO}_{2}$ and pollutant mixing ratios were integrated in consecutive intervals of 30,60 , 90 , and $120 \mathrm{~s}$ and fuel-based emission factors were calculated according to Eq. (1).

This approach assumes that LOCAL mixing ratios are solely due to vehicle emissions (in reality, they may also contain point sources or other types of emissions, including those not associated with combustion). The purpose of this calculation was twofold. First, we were interested in determining whether this computationally simple approach could yield realistic fleet-average emission factors comparable to those obtained using the plume-based approach. Second, we were interested in determining EFs for pollutants not sharing a common inlet with $\mathrm{CO}_{2}$ (i.e., for benzene during the winter, and $\mathrm{HNCO}$ and $\mathrm{HCN}$ during the summer), which would allow for a seasonal comparison. Here, the assumption is that, when integrating over a sufficiently long interval of time, the majority of vehicle plumes are captured by both inlets (i.e., both the $\mathrm{CO}_{2}$ and pollutant $X$ are detected) and that meteorology or turbulence affects the dilution of the pollutant and $\mathrm{CO}_{2}$ equally.

\section{Results and discussion}

\subsection{Overview of mobile pollutant measurements}

Ambient pollutant concentration statistics for the summer campaign (benzene, toluene, $\mathrm{C} 2$ benzenes, $\mathrm{NO}_{2}, \mathrm{NO}, \mathrm{CO}_{2}$, $\mathrm{PN}, \mathrm{BC}, \mathrm{HNCO}$, and $\mathrm{HCN}$ ) and winter campaign (benzene, $\mathrm{HNCO}, \mathrm{HCN}$, and $\mathrm{CO}_{2}$ ) are shown in Table 1 . The $\mathrm{BC}$ concentrations reported in this study are comparable to the range $\left(0.10-1.7 \mu \mathrm{g} \mathrm{m}^{-3}\right)$ previously reported for Toronto (Knox et al., 2009; Chan et al., 2011).

The ambient HNCO concentrations measured during this study are similar in magnitude to those measured by others (Roberts et al., 2011, 2014; Woodward-Massey et al., 2014; Zhao et al., 2014; Wentzell et al., 2013) for urban locations with minimal BB influence, which range from ca. 10 to 85 pptv. However, Chandra and Sinha (2016) report annual HNCO mixing ratios of $0.94 \mathrm{ppbv}$ for a suburban site in the Indo-Gangetic Plain that is strongly influenced by cropresidue fires; a much higher average summertime HNCO concentration of $1.7 \pm 0.06 \mathrm{ppbv}$ was recently measured at the same site (Kumar et al., 2018). Our measurements for both the summer and winter periods are slightly lower than the summertime mean mixing ratio of 85 pptv previously reported for a fixed location in Toronto (Wentzell et al., 2013). However we note that the authors found that $\mathrm{HNCO}$ was generally highest between the hours of 18:00 and 22:00 LT. In the present study, the measurements are limited to the driving period, which could explain the slightly lower mean $\mathrm{HNCO}$ concentration. Overall, the magnitudes of the HNCO mixing ratios in both seasons $(\sim 45$ and $\sim 26 \mathrm{pptv}$ for the summer and winter respectively) are much lower than the $1 \mathrm{ppbv}$ harm threshold (Roberts et al., 2011; Wang et al., 2007).

The HCN mixing ratios measured in this study are 2 orders of magnitude lower than the mean $\mathrm{HCN}$ mixing ratios of $3.45 \pm 3.43 \mathrm{ppbv}$ (continuous sampling from a near-road location) and $1.57 \pm 0.33 \mathrm{ppbv}$ (mobile measurements in heavy traffic) previously reported for Toronto (Moussa et al., 2016). Long-path FTIR measurements of HCN (1 min time resolution) were made above the busy Highway 401 in Toronto concurrent with the present study (July-August 2015) (You et al., 2017). Consistent with our low HCN measurements, the authors found that HCN mixing ratios only spiked above the FTIR method detection limit of 3.2 ppbv on three occasions (isolated $1 \mathrm{~min}$ data points). Although prior measurements (Moussa et al., 2016) seem exceptionally high, our measurements are also on the low end of those reported for ground-level, ambient $\mathrm{HCN}$ in a rural region with little forest fire impact, which are on the order of a few hundred pptv (Ambrose et al., 2012). No significant long-term changes have been observed or expected for tropospheric HCN (Zhao et al., 2002) so it is unclear as to why the present measurements are so low. However, the vast majority of HCN measurements have focused on regions influenced by biomass burning and have been made aloft; measurements of $\mathrm{HCN}$ at 
ground level in urban areas are severely lacking. More measurements of $\mathrm{HCN}$ in urban environments are required in order to better characterize HCN concentration gradients and population exposure in regions with minimal biomass burning influence.

\section{Local (on-road) and background contributions: a seasonal comparison}

Figure 1 shows histograms as a function of season for the measured ambient concentrations as well as for the background (BKG) and on-road (LOCAL) contributions for (a) HNCO and (b) HCN; Fig. S4 shows similar histograms for (a) benzene and (b) black carbon. Figure 2 shows the mean BKG and LOCAL contributions to the measured ambient concentration for the four pollutants, as a function of season. For both benzene and BC, the LOCAL contribution is dominant, indicating strong traffic sources for these pollutants. We observed a small seasonal dependence in ambient benzene, with overall higher concentrations in the winter than in the summer, as observed by others (Tan et al., 2014; Lough et al., 2005). Separation of the observations into the BKG and LOCAL contributions reveals that the shift is largely in the LOCAL contribution rather than the BKG contribution, consistent with an enhanced wintertime emission factor for benzene (Tan et al., 2014; Lough et al., 2005), attributed to higher cold-start emissions and changes in fuel composition. An enhancement in wintertime benzene concentrations may also be partially attributed to an increase in benzene emissions from residential wood combustion (e.g., wood stoves, fireplaces). This enhancement would manifest in the BKG contribution (which is indeed slightly higher in the winter than the summer). On a national scale, this source is significant (CCME, 2012); however, in urban areas, wood heating is the primary home heating fuel for $<0.1 \%$ of residences (Matz et al., 2015), and so it is unlikely that this source is significant within the GTA. Increases in wintertime benzene may also be attributed to a shallower boundary layer height. A seasonal comparison is not available for black carbon.

To our knowledge, our dataset represents the first seasonal comparison of ambient $\mathrm{HNCO}$ measurements made at the same location. Figure 2c illustrates a decrease in HNCO concentrations from the summer to the winter. Shallower boundary layer heights would be expected to lead to enhanced wintertime concentrations if $\mathrm{HNCO}$ emissions and sources remain constant, and yet we observe lower concentrations of $\mathrm{HNCO}$ in the winter. Hence the boundary layer height is a potential issue that can reduce the apparent differences between summer and winter. Further inspection of Figs. 1a and $2 \mathrm{c}$ reveals that the seasonal difference is largely in the BKG contribution rather than the LOCAL contribution. The lower HNCO mixing ratios in the winter could be due to a reduction in photochemical activity and/or source strength of secondary HNCO precursors (e.g., bio- genic amines) (Woodward-Massey et al., 2014; Roberts et al., 2014), or due to decreased influence from biomass burning. However, the extent to which wild fires contribute to summertime HNCO concentrations is not well established and may be less significant given HNCO's moderate lifetime (as short as a few hours in clouds, but typically weeks to hundreds of years) (Borduas et al., 2016; Barth et al., 2013; Zhao et al., 2014) and the distant location of major Canadian wildfire events relative to Toronto. Although residential wood burning could also contribute to HNCO across the GTA in the winter, a recent study by Coggon et al. (2016) showed that common residential wood fuels (e.g., heartwood and sapwood) have low nitrogen content and thus lower emissions of nitrogen-containing VOCs such as HNCO and HCN. Consistent with this finding and the low incidence of residential wood burning in the GTA (Matz et al., 2015), the HNCO BKG component is low in the winter. Rather, the LOCAL component dominates the contribution to the measured $\mathrm{HNCO}$ in the winter, indicating the significance of onroad emissions as an HNCO source. Although lower temperatures are thought to enhance $\mathrm{HNCO}$ vehicle emissions (particularly cold-start emissions) (Suarez-Bertoa and Astorga, 2016), the similarity in the magnitude of the LOCAL component between seasons suggests that, overall, the primary on-road $\mathrm{HNCO}$ emissions remain relatively constant.

Similar to HNCO, we observe a strong seasonal dependence for HCN. The histogram in Fig. 1b shows a much broader distribution and higher mean for the summer compared to the winter (Fig. 2d). Separation of the observations into BKG and LOCAL contributions in Fig. 1b reveals a strong seasonal difference for both components, although the difference is more striking for the BKG component. As with $\mathrm{HNCO}$, despite shallower boundary layer heights in the winter, the overall concentrations are observed to be lower in the winter. The same arguments regarding the potential impact of residential wood burning on wintertime $\mathrm{HNCO}$ emissions apply to HCN. The large increase in BKG in the summer is consistent with the wildfire season in Canada, and that biomass burning is thought to be the major source of $\mathrm{HCN}$ to the atmosphere. Given the relatively long lifetime of HCN ( 2-5 months) (Li et al., 2003) compared to HNCO, biomass burning episodes in other parts of Canada would be expected to have a greater potential to influence background $\mathrm{HCN}$ in Toronto compared to HNCO. A strong seasonal pattern for $\mathrm{HCN}$ has previously been observed for tropospheric HCN column measurements (Zhao et al., 2002); seasonal measurements of $\mathrm{HCN}$ at an urban location have not been made. The bulk of the total measured HCN concentration is in the BKG component rather than the LOCAL component, especially in the summer, suggesting that, in relative terms, on-road HCN sources may be less significant than other regional or global sources. This is in contrast to benzene (dominant LOCAL component in both seasons) and HNCO (dominant LOCAL component only in the winter). Interestingly, examination of Fig. $1 \mathrm{~b}$ also reveals a strong seasonal de- 

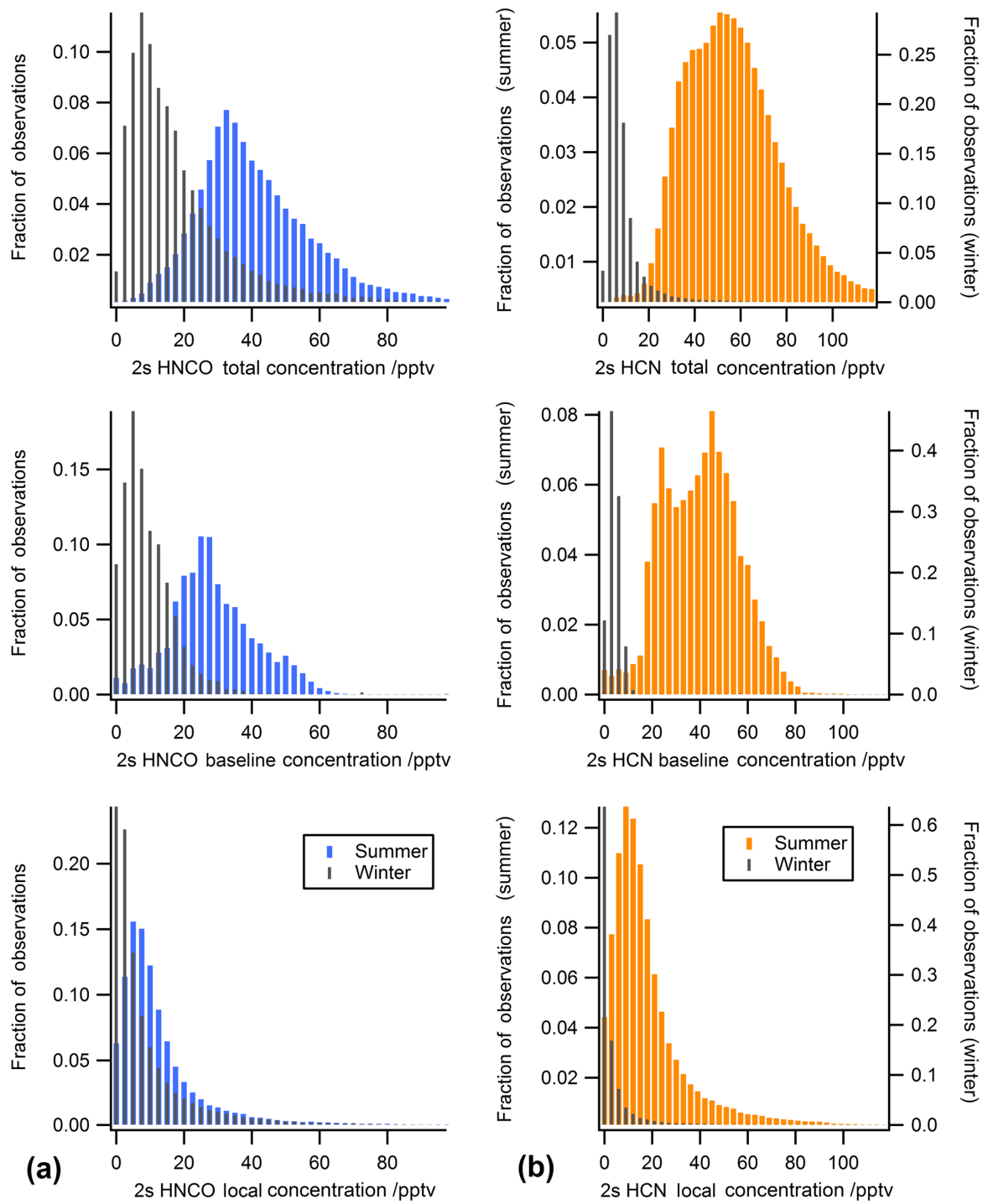

Figure 1. Distribution of ambient mixing ratios for (a) HNCO and (b) HCN. Top panel: total concentration. Middle panel: background (BKG) concentration. Bottom panel: background-corrected (LOCAL) concentration. Summer campaign (July 2015) shown as colored bars; winter campaign (January 2016) shown as grey bars.

pendence in the LOCAL component, suggesting a possible seasonal dependence in the on-road HCN emissions, as discussed below (Sect. 3.3.3).

\subsection{Comparison of plume-based vs. time-based emission factor methodologies}

A discussion of trends within the plume-based and timebased emission factors, as well as a thorough comparison of the two methodologies, can be found in the Supplement for all species (Tables S6 and S7). Median EFs calculated using both the plume-based SPP approach and time-based approach (120 s interval) are also compared graphically in Fig. 3 for benzene, HNCO, and HCN. We find the time- based approach yields much higher $(>80 \%)$ median EFs for black carbon and NO than the plume-based approach. As discussed in the Supplement, the exact reason for the discrepancy is not known. However we note that both $\mathrm{BC}$ and $\mathrm{NO}$ are strongly associated with HDDVs and thus exhibit highly skewed EF distributions and that the time-based approach does not appear to adequately capture the small EF end of these distributions (Fig. S6). In contrast, we find that the two approaches yield median EFs within $25 \%$ for species associated with LDGV emissions (benzene, toluene, $\mathrm{C} 2$ benzenes, $\mathrm{NO}_{2}$, PN, HNCO, and HCN) (see Fig. 3, Tables S6 and S7). The ability of the time-based methodology to capture similar EF trends (Fig. S7) and magnitudes as the plume-based approach for the majority of pollutants shows that this com- 

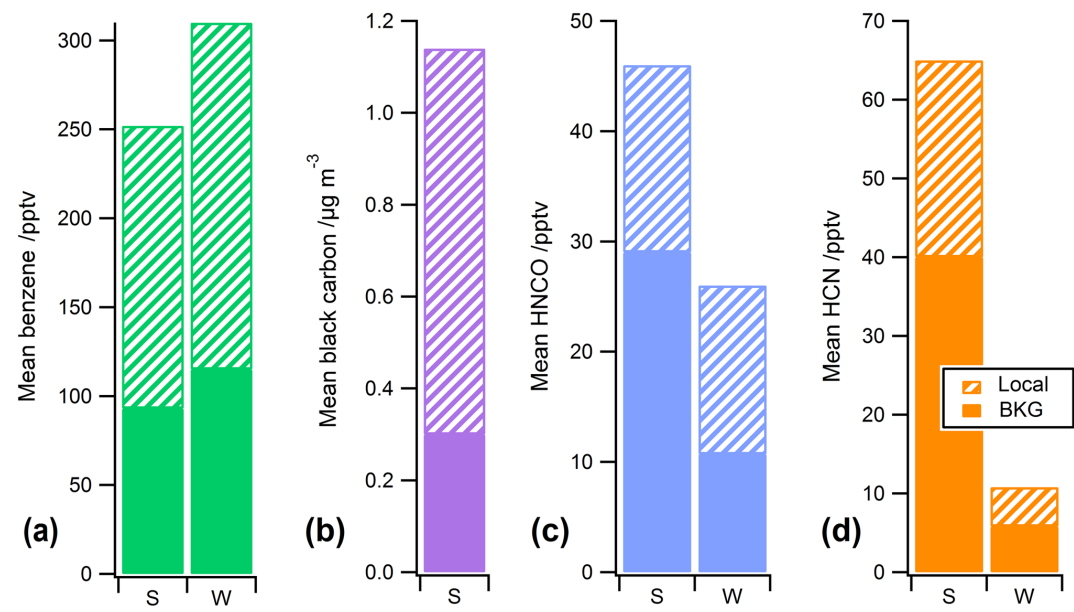

Figure 2. Mean on-road (LOCAL, patterned) and background (BKG, solid) mixing ratios for the summer (S) and winter (W) campaigns. (a) Benzene, (b) BC, (c) $\mathrm{HNCO}$, and (d) $\mathrm{HCN}$.
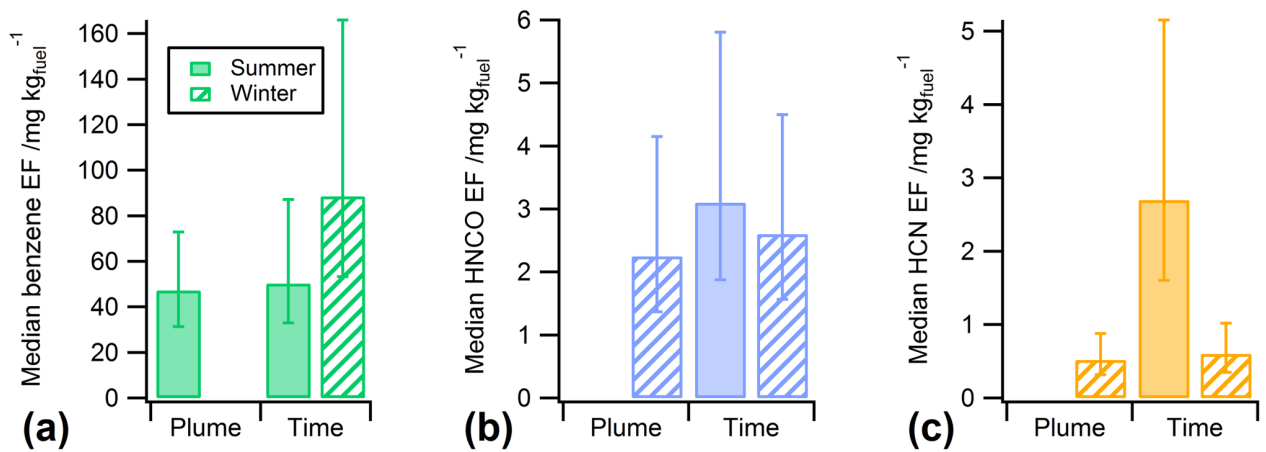

Figure 3. Median emission factors for (a) benzene, (b) HNCO, and (c) HCN calculated using the SPP plume-based approach (Plume) or the time-based approach with an integration period of $120 \mathrm{~s}$ (Time). The error bars show the interquartile range. Values obtained from the summer campaign (solid bars) and winter campaign (patterned bars).

putationally simple analysis can provide basic insight regarding fleet-average emissions, although more work is required to fully understand the conditions and pollutants which are best suited to this approach. In the current study, the advantage of the time-based methodology is its ability to reveal seasonal trends in emission factors, which are reflections of the changing LOCAL (on-road) contributions. However, this method could potentially have useful applications for monitoring long-terms trends in vehicle emissions using nearroad surveillance data or data from instruments with insufficient time resolution for a plume-based analysis. Since the LOCAL component used in the analysis may also include near-road or non-mobile sources, the EFs calculated using this method likely represent an upper bound.

Ultimately, periods of vehicle exhaust are defined with the highest confidence using the plume-based SPP approach and so we expect that this methodology yields the most accurate EFs. Because individual plumes are more likely to be associated with specific vehicles using this methodology, it also provides insight as to the variability of vehicle EFs and the presence of high-emitters within the fleet. Since the mean and standard deviation are sensitive to distortion by the presence of high-emitting vehicles in our modest sample sizes, we, and others (Westerdahl et al., 2009), suggest that the median and interquartile range (IQR) are more representative metrics for comparison with literature emission factors and for estimating inventories. Therefore all further discussion focuses on median EFs obtained using the plume-based SPP methodology unless stated otherwise. The distribution histograms of plume-based EFs are shown in Fig. 4 for benzene, BC, $\mathrm{HNCO}$, and $\mathrm{HCN}$ and in Fig. S5 for others traffic pollutants (toluene, $\mathrm{C} 2$ benzenes, $\mathrm{NO}, \mathrm{NO}_{2}, \mathrm{NO}_{x}$, and $\mathrm{PN}$ ).

\subsection{Plume-based fleet emission factors for common traffic pollutants}

Our results are now compared to literature EFs for common traffic pollutants (benzene, toluene, $\mathrm{C} 2$ benzenes, $\mathrm{NO}_{x}, \mathrm{PN}$, 
BC). In the subsequent sections, the fleet-average EFs estimated for black carbon, $\mathrm{HNCO}$, and $\mathrm{HCN}$ are discussed in further detail.

Plume-based median, mean, and interquartile range SPP EFs for a number of traffic pollutants are listed in Table 2, along with literature EFs obtained from tunnel, mobile, near-road or remote-sensing studies. The median and mean plume-based EFs calculated here are consistent with, but generally fall on the lower-end of, the EFs reported in the literature. The lower EFs obtained here may be a result of the study location: fleet-average EFs are highly sensitive to the make-up of the vehicle fleet (i.e., vehicle age, proportion of gasoline vs. diesel vehicles, after-treatment technologies in use), which is in turn location dependent (Kristensson et al., 2004; Zavala et al., 2006). Furthermore, EFs from previous studies may no longer be relevant due to improvements in emissions control technologies, removal of high-emitting vehicles, fleet turnover, and changes in regulations. Significant multidecadal decreases in vehicle emissions of $\mathrm{CO}$, VOC, $\mathrm{NO}_{x}, \mathrm{PM}_{2.5}$, and $\mathrm{BC}$ have been observed previously (Jiang et al., 2005; McDonald et al., 2012, 2013; Ban-Weiss et al., 2008; Bishop and Stedman, 2008; Dallmann et al., 2013).

Thus, the low fleet-average EFs obtained in this study indicate that the GTA fleet is clean relative to some of those listed for comparison in Table 2. In 1999, the government of Ontario introduced a vehicle testing program (Drive Clean) aimed at improving air quality by identifying and removing or repairing high-emitting vehicles and resulting in a considerable decrease in smog-causing pollutants $\left(\mathrm{NO}_{x}\right.$ and total hydrocarbons) of about $16 \%$ from program inception to 2010 (McCarter, 2012). Coincident with changes in gasoline regulations for benzene and other technology improvements, Canada introduced a Canada-Wide Standard for Benzene in 2010. Since then, the transportation sector has led a dramatic reduction in national average ambient concentrations of benzene, particularly in urban locations (CCME, 2012). Our relatively low EFs are hence consistent with the successful implementation of these and other policies, such as reduction in fuel sulfur content.

The most recent emission factor measurements for comparison were made at a near-road location in Toronto in 2013 and 2014 (Wang et al., 2015). The mean and median EFs for the VOCs, $\mathrm{NO}_{x}, \mathrm{PN}$, and $\mathrm{BC}$ obtained here are in excellent agreement with those reported by Wang et al. (2015) (see Figs. 4 and S5). The approach for determining EFs presented here differs in (a) its mobile nature, covering a wide geographical area and range of road types and (b) its short time period (i.e., limited number of captured plumes). However, the mobile nature of our study results in a higher likelihood of sampling exhaust from a larger spectrum of vehicle types (including HDDVs) under a greater range of real-world driving conditions. The good agreement between the two studies for a wide range of pollutants gives confidence that our methodology provides representative fleet-average emission factors despite a smaller sample size. In this way the current study compliments the stationary study (Wang et al., 2015), demonstrating that the EFs obtained at their fixed location are applicable across a large region.

\subsubsection{Black carbon emission factors}

We obtained plume-based median and mean black carbon emission factors of 24.9 and $85.6 \mathrm{mg} \mathrm{kg}_{\text {fuel }}^{-1}$ respectively (IQR: $10.3-76.4 \mathrm{mg} \mathrm{kg}_{\text {fuel }}^{-1}$ ). BC emission factors obtained by prior tunnel, near-road, and mobile studies are listed in Table $\mathrm{S} 9$ for comparison. Literature emission factors for heavyduty diesel vehicles range from $160-2400 \mathrm{mg} \mathrm{kg}_{\text {fuel }}^{-1}, 1$ to 2 orders of magnitude higher than the literature emission factors for light-duty gasoline vehicles, which range from $\sim 1$ to $300 \mathrm{mg} \mathrm{kg}_{\text {fuel }}^{-1}$. LDGV emission factors at the high end of this range are from older studies in more polluted environments (Westerdahl et al., 2009). In many of the earlier studies, BC emission factors were obtained using an aethalometer with a $1 \mathrm{~min}$ time resolution, which may not have been fast enough to accurately quantify $\mathrm{BC}$ emission factors. In the current study, the poor performance of the time-based approach with respect to yielding BC EFs in agreement with the plumebased approach may also indicate that high-time-resolution measurements of $\mathrm{BC}$ and good plume definition are required to accurately estimate $\mathrm{BC}$ EFs from mobile measurements. However, more comparisons are needed to determine if and how calculated $\mathrm{BC}$ EFs depend upon the $\mathrm{BC}$ measurement method.

As was observed for the other pollutants (benzene, $\mathrm{NO}_{x}$, $\mathrm{PN}$ etc.), the $\mathrm{BC}$ emission factors obtained in this study are on the lower end of the reported literature range. Two studies have made recent measurements of the mixed vehicle fleet in Toronto. Wang et al. (2015) made BC EF measurements from their near-road stationary site in downtown Toronto using a photoacoustic soot photometer and report a mean EF of (35-55) $\mathrm{mg} \mathrm{kg}_{\text {fuel }}^{-1}$. Liggio et al. (2012) obtained BC EFs from transect driving downwind, and perpendicular to, a major Toronto highway (mean HDDV fraction $\sim 3.3 \%$ ). The authors report fleet-average median emission factors of $59.3 \mathrm{mg} \mathrm{kg}_{\text {fuel }}^{-1}$ (IQR: $27.0-148.4 \mathrm{mg} \mathrm{kg}_{\text {fuel }}^{-1}$ ) using a HS-LII instrument and $29.4 \mathrm{mg} \mathrm{kg}_{\text {fuel }}^{-1}$ (IQR: $11.8-66.0 \mathrm{mg} \mathrm{kg}_{\text {fuel }}^{-1}$ ) using a single-particle soot photometer. The values from these two studies (Wang et al., 2015; Liggio et al., 2012) lie between the median and mean obtained in the current study.

The lower values obtained in this study compared to Liggio et al. could be reflective of overall changes in the vehicle fleet over the past 5 years leading to reductions in BC emissions, consistent with observations at other locations (BanWeiss et al., 2008; Dallmann et al., 2012). The discrepancy between our study and the other two Toronto studies could also be related to location: their fixed/limited sites may not be representative of the full fleet across the GTA. Given the difference in LDGVs and HDDV BC EFs, the emission factor calculation will be quite sensitive to the frequency at which each vehicle type is sampled, which will be location depen- 

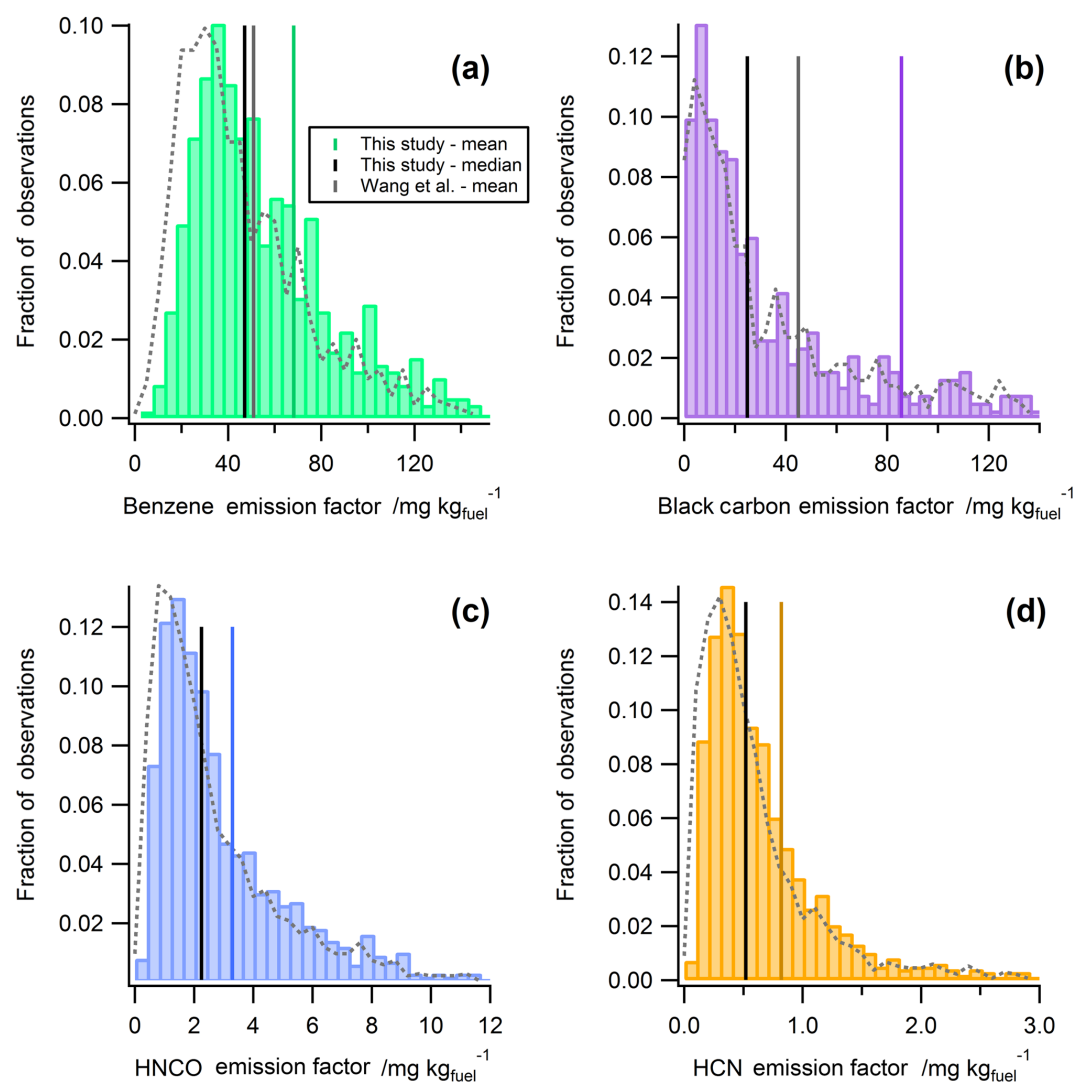

Figure 4. Plume-based emission factors obtained by CRUISER for (a) benzene, (b) BC, (c) HNCO, and (d) HCN for the SPP case (colored bars) and the MPP case (grey, dashed line). The median and mean EF values are indicated by the vertical black and colored lines respectively. Where available, the mean EF obtained by Wang et al. (2015) is indicated by the vertical grey line.

dent. This sensitivity can be quite dramatic: a recent study (Dallmann et al., 2013) found that, due to their higher associated BC emissions, even a small fraction $(<1 \%)$ of heavyduty trucks can significantly bias the calculated LDGV emission factors (by over $40 \%$ ). For a pollutant exhibiting wide inter- and intra-vehicle variation in EFs, obtaining measurements that capture the full fleet make-up over a range of driving conditions is critical. Although we did not record the number of HDDVs (expected fraction $\sim 4 \%$ ), the mobile design and scope of our study helps to mitigate locationspecific results. Overall, we found that the top $4 \%$ of plumes had vehicle emissions greater than $320 \mathrm{mg} \mathrm{kg}_{\text {fuel }}^{-1}$ which are typical of heavy-duty vehicles.

\subsubsection{HNCO emission factors}

As previously mentioned, literature $\mathrm{HNCO}$ EFs have been obtained exclusively from a limited number of dynamometer studies (on both gasoline and diesel vehicles) and so a comprehensive understanding of the real-world magnitude and variability of HNCO EFs is lacking. Here we obtain the first fleet-average EFs for HNCO. Table 3 compares the HNCO emission factors available in the literature with the winter- time plume-based HNCO median EF obtained in this study $\left(2.3 \mathrm{mg} \mathrm{kg}_{\text {fuel }}^{-1}\right)$. Our time-based analysis (Fig. 3b) suggests that HNCO EFs are similar in the summer and winter (with slightly higher EFs in the summer, contrary to the behavior of benzene).

Only two previous dynamometer studies (Brady et al., 2014; Suarez-Bertoa and Astorga, 2016) obtained HNCO emission factors from gasoline vehicles and the average EFs reported from those studies differ by more than 1 order of magnitude. HCNO was measured by Acetate-TOFCIMS and Fourier-transform infrared spectroscopy in the former (Brady et al., 2014) and latter (Suarez-Bertoa and Astorga, 2016) studies respectively. The plume-based median EF obtained in this study is about a factor of 2 higher than that obtained by the earlier study (fleet average of $0.91 \pm 0.58 \mathrm{mg} \mathrm{kg}_{\text {fuel }}^{-1}$ for eight LDGVs) (Brady et al., 2014), but significantly lower than that obtained more recently (fleet average of $93 \mathrm{mg} \mathrm{kg}_{\text {fuel }}^{-1}$ for three LDGVs, or $29 \mathrm{mg} \mathrm{kg}_{\text {fuel }}^{-1}$ if the anomalously high LDGVs are omitted) (Suarez-Bertoa and Astorga, 2016).

Interestingly, emission factors ranging from 0.21 to $3.96 \mathrm{mg} \mathrm{kg}_{\text {fuel }}^{-1}$ were recently obtained from an engine dynamometer study on a single light-duty diesel engine, in 
Table 2. Plume-based median and mean emission factors calculated using single-peak plumes (SPP) for the summer and winter campaigns. Interquartile range (25th-75th percentile) shown in brackets. Units for numerator given in the pollutant column, units for denominator given in the header.

\begin{tabular}{|c|c|c|c|c|}
\hline Pollutant and units & $\begin{array}{l}\text { Fuel-based } \\
\text { units/ } \\
\mathrm{kg}_{\text {fuel }}^{-1}\end{array}$ & $\begin{array}{r}\text { Distance- } \\
\text { based } \\
\text { units }^{\mathrm{a}} / \\
\mathrm{km}^{-1}\end{array}$ & $\begin{array}{r}\text { Literature } \\
\text { range } \\
\text { fuel-based } \\
\text { units } \mathrm{b} / \\
\mathrm{kg}_{\text {fuel }}^{-1}\end{array}$ & References \\
\hline \multicolumn{5}{|l|}{ Summer } \\
\hline Benzene/mg & $\begin{array}{r}47.2,68.2 \\
(31.3-72.8)\end{array}$ & $3.7,5.7$ & $28-650$ & $\begin{array}{l}\text { Gentner et al. (2013), Hwa et al. (2002), } \\
\text { Wang et al. (2015), Araizaga et al. (2013), } \\
\text { Ho et al. (2009), Zavala et al. (2009), } \\
\text { Kristensson et al. (2004) }\end{array}$ \\
\hline Toluene/mg & $\begin{array}{r}101.6,179.5 \\
(62.5-194.6)\end{array}$ & $8.4,14.9$ & 50-2075 & $\begin{array}{l}\text { Hwa et al. (2002), Gentner et al. (2013), } \\
\text { Wang et al. (2015), Araizaga et al. (2013), } \\
\text { Ho et al. (2009), Zavala et al. (2009), } \\
\text { Kristensson et al. (2004) }\end{array}$ \\
\hline $\mathrm{C} 2$ Benzenes $\mathrm{c} / \mathrm{mg}$ & $\begin{array}{r}76.8,147.6 \\
(44.8-149.7)\end{array}$ & $6.4,12.2$ & $74-1455$ & $\begin{array}{l}\text { Hwa et al. (2002), Gentner et al. (2013), } \\
\text { Wang et al. (2015), Araizaga et al. (2013), } \\
\text { Ho et al. (2009), Zavala et al. (2009), } \\
\text { Kristensson et al. (2004) }\end{array}$ \\
\hline $\mathrm{NO}_{2}{ }^{\mathrm{d}} / \mathrm{g}$ & $\begin{array}{r}1.15,1.39 \\
(0.56-1.85)\end{array}$ & $0.095,0.115$ & & \\
\hline $\mathrm{NO}^{\mathrm{d}} / \mathrm{g}$ & $\begin{array}{r}1.03,1.79 \\
(0.38-2.20)\end{array}$ & $0.086,0.148$ & & \\
\hline $\mathrm{NO}_{x}\left(=\mathrm{NO}+\mathrm{NO}_{2}\right) / \mathrm{g}$ & $\begin{array}{r}2.27,3.13 \\
(1.16-4.23)\end{array}$ & $0.188,0.259$ & $1.4-42$ & $\begin{array}{l}\text { Wang et al. (2015), Kristensson et al. } \\
\text { (2004), Hwa et al. (2002), Jiang et al. } \\
\text { (2005), Hudda et al. (2013), Park et al. } \\
\text { (2011), Dallmann et al. (2013), } \\
\text { Kirchstetter et al. (1999), Ban-Weiss et } \\
\text { al. (2008) }\end{array}$ \\
\hline Particle counts $/ 10^{14}$ counts & $\begin{array}{r}8.3,15.9 \\
(3.7-20.0)\end{array}$ & $0.69,1.32$ & $3.9-57.4$ & $\begin{array}{l}\text { Wang et al. (2015), Kristensson et al. } \\
\text { (2004), Hudda et al. (2013), Ban-Weiss et } \\
\text { al. (2010) }\end{array}$ \\
\hline Black carbon/mg & $\begin{array}{r}24.9,85.6 \\
(10.3-76.4)\end{array}$ & $2.1,7.1$ & $10-2400$ & Literature comparison in Table $\mathrm{S} 9$ \\
\hline \multicolumn{5}{|l|}{ Winter } \\
\hline $\mathrm{HNCO} / \mathrm{mg}$ & $\begin{array}{r}2.25,3.30 \\
(1.37-4.15)\end{array}$ & $0.126,0.274$ & & Literature comparison in Table 5 \\
\hline $\mathrm{HCN} / \mathrm{mg}$ & $\begin{array}{r}0.52,0.82 \\
(0.32-0.88)\end{array}$ & $0.043,0.068$ & & Literature comparison in Table 6 \\
\hline \multicolumn{5}{|c|}{ 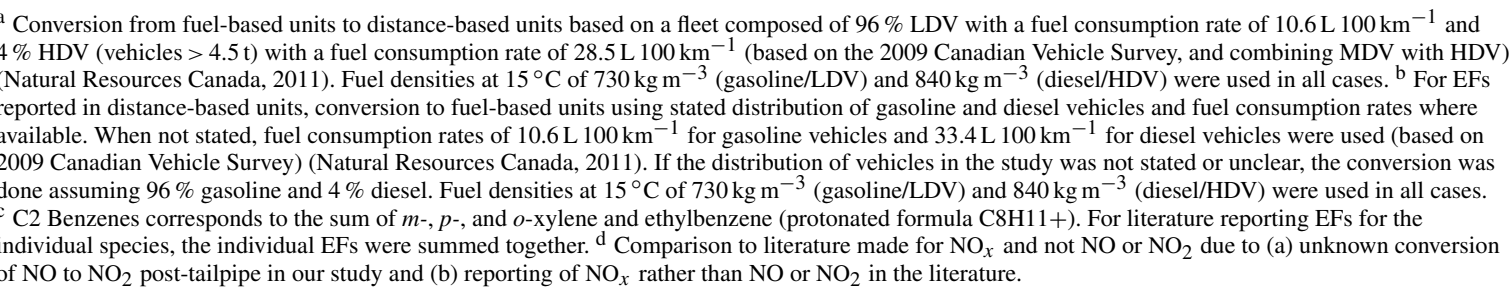 } \\
\hline
\end{tabular}

agreement with the results from the current study (Wentzell et al., 2013). This may suggest that HNCO emissions from gasoline and diesel vehicles are of similar magnitude. In contrast, HNCO emission factors for an off-road diesel engine have been found to be 1 order of magnitude higher, and it has been suggested that the magnitude and range of HNCO emissions, as well as their dependence on operating conditions, could be different for this type of engine (larger, off-road 
Table 3. Comparison of literature HNCO emission factors from the exhaust of various gasoline- and diesel-fueled engines in fuel-based units $\left(\mathrm{mg} \mathrm{kg}_{\text {fuel }}^{-1}\right)$.

\begin{tabular}{|c|c|c|c|c|c|}
\hline Reference & Type of study & $\begin{array}{l}\mathrm{HNCO} \\
\text { detection }\end{array}$ & $\begin{array}{l}\text { Range/ } \\
\mathrm{mg} \mathrm{kg}_{\text {fuel }}^{-1}\end{array}$ & $\begin{array}{l}\text { Average/ } \\
\mathrm{mg} \mathrm{kg}_{\text {fuel }}^{-1}\end{array}$ & Description of vehicle and fuel \\
\hline This study & Mobile & HR-TOF-CIMS & $1.4-4.2^{\mathrm{a}}$ & $\begin{array}{l}2.3,3.3^{\mathrm{b}} \\
2.6,4.0 \\
3.1,5.4\end{array}$ & $\begin{array}{l}\text { Winter fleet, plume based (SPP) } \\
\text { Winter fleet, time based }(120 \mathrm{~s}) \\
\text { Summer fleet, time based }(120 \mathrm{~s})\end{array}$ \\
\hline $\begin{array}{l}\text { Wentzell et al. } \\
(2013)\end{array}$ & $\begin{array}{l}\text { Engine } \\
\text { dynamometer }\end{array}$ & Acetate-TOF-CIMS & $0.21-3.96$ & NA & $\begin{array}{l}2011 \text { Jetta equipped with turbo diesel } \\
\text { injection (TDI) and diesel oxidation } \\
\text { catalyst (DOC) }\end{array}$ \\
\hline $\begin{array}{l}\text { Brady et al. } \\
(2014)\end{array}$ & $\begin{array}{l}\text { Chassis } \\
\text { dynamometer }\end{array}$ & Acetate-TOF-CIMS & $\begin{array}{l}0.45-1.70 \\
\text { (fleet averages } \\
\text { for the } 4 \\
\text { phases) }\end{array}$ & $\begin{array}{l}0.91 \pm 0.58 \\
\text { (full fleet, entire } \\
\text { drive cycle) }\end{array}$ & $\begin{array}{l}8 \text { LDGVs equipped with a three-way } \\
\text { catalyst (TWC) }\end{array}$ \\
\hline $\begin{array}{l}\text { Suarez-Bertoa } \\
\text { and Astorga } \\
(2016)\end{array}$ & $\begin{array}{l}\text { Chassis } \\
\text { dynamometer }\end{array}$ & FTIR & NA & $\begin{array}{l}30\left(23^{\circ} \mathrm{C}\right)^{\mathrm{c}} \\
140\left(-7^{\circ} \mathrm{C}\right)^{\mathrm{c}} \\
93\left(23^{\circ} \mathrm{C}\right)^{\mathrm{d}} \\
29\left(23^{\circ} \mathrm{C}\right)^{\mathrm{e}}\end{array}$ & $\begin{array}{l}10 \text { LDVs: } 3 \text { LDGVs, } 4 \text { LDDVs (light-duty } \\
\text { diesel vehicles), } 2 \text { flex-fuel } \\
\text { LDVs, } 1 \text { electric LDV; varying } \\
\text { after-treatment }\end{array}$ \\
\hline $\begin{array}{l}\text { Heeb et al. } \\
(2011)\end{array}$ & $\begin{array}{l}\text { Engine } \\
\text { dynamometer }\end{array}$ & $\begin{array}{l}\text { Offline LC-MS } \\
\text { analysis, after } \\
\text { derivatization }\end{array}$ & NA & $\begin{array}{l}29 \text { (with combined } \\
\text { DPF-SCR system) } \\
32 \text { (with } \mathrm{V}_{2} \mathrm{O}_{5} \text {-based } \\
\text { SCR system) }\end{array}$ & $\begin{array}{l}\text { Diesel engine with a turbo charger and } \\
\text { direct fuel engine, with and without } \\
\text { selective catalytic reduction (SCR) and } \\
\text { without a diesel particulate filter (DPF) }\end{array}$ \\
\hline $\begin{array}{l}\text { Jathar et al. } \\
\text { (2017) }\end{array}$ & $\begin{array}{l}\text { Engine } \\
\text { dynamometer }\end{array}$ & Acetate-TOF-CIMS & $31-56$ & NA & $\begin{array}{l}\text { John Deere PowerTech Plus (off-road) } \\
\text { diesel engine with DOC and DPF, with } \\
\text { and without SCR; diesel and biodiesel }\end{array}$ \\
\hline $\begin{array}{l}\text { Link et al. } \\
(2016)\end{array}$ & $\begin{array}{l}\text { Engine } \\
\text { dynamometer }\end{array}$ & Acetate-TOF-CIMS & NA & $\begin{array}{l}54 \pm 3(\text { Idle }) \\
17 \pm 2(50 \% \text { load })\end{array}$ & $\begin{array}{l}\text { Same engine as above, with no DOC, } \\
\text { DPF, or SRC; diesel and biodiesel }\end{array}$ \\
\hline
\end{tabular}

${ }^{a}$ Interquartile range; ${ }^{\mathrm{b}}$ median, mean; ${ }^{\mathrm{c}}$ fleet median for all 10 vehicles (all other values in the paper are reported in distance-based units mg km ${ }^{-1}$ ); ${ }^{\mathrm{d}}$ mean for the three gasoline vehicles (LDGVs); ${ }^{\mathrm{e}}$ mean for the gasoline vehicles omitting GV3 (anomalously high EFs).

diesel engine) (Link et al., 2016; Jathar et al., 2017). Much of the early work on $\mathrm{HNCO}$ vehicle emissions was prompted by the finding that selective catalytic reduction (SCR) systems could constitute an important source of HNCO (Kröcher et al., 2005; Heeb et al., 2011, 2012), but the impact of SCR systems (or other control technologies such as the diesel particulate filter, DPF, or diesel oxidation catalyst, DOC) is disputed (Jathar et al., 2017).

In addition to a wide range of emission factors, the available literature revealed conflicting information on the conditions leading to elevated HNCO emissions, as well as high inter-vehicle variability. HNCO emissions have been observed to vary by as much as 1 order of magnitude depending on the driving cycle, but the influence of hard acceleration and cold engine starting is contested (Brady et al., 2014; Suarez-Bertoa and Astorga, 2016). Similarly, studies have demonstrated opposite trends for idle vs. active operating conditions (Link et al., 2016; Wentzell et al., 2013). For all these reasons, a direct comparison of the EF obtained in this study to reported EFs is challenging. The current study cannot reveal the mechanism of HNCO production from diesel or gasoline vehicles, or its dependence on factors such as driving condition and the presence of various after-treatment technologies. However, a key strength of our study is that it is based upon a large number of vehicles operating on-road in real-world conditions, thus implicitly reflecting a range of these factors. Therefore, we suggest that the IQR reported here $\left(1.37-4.15 \mathrm{mg} \mathrm{kg}_{\text {fuel }}^{-1}\right)$ along with the overall distribution of measured HCNO EFs (Fig. 4c) provides the most realistic constraint to date on the magnitude and variability of $\mathrm{HNCO}$ emissions.

\subsubsection{HCN emission factors}

As with $\mathrm{HNCO}$, EFs for $\mathrm{HCN}$ have been obtained exclusively from a limited number of dynamometer studies. Table 4 lists HCN emission factors obtained in this study along with those obtained from prior dynamometer studies; here distance-based units $\left(\mathrm{mg} \mathrm{km}^{-1}\right)$ are used for ease of comparison. The seasonal dependence of $\mathrm{HCN}$ vehicle emissions has not been previously studied. Interestingly, Fig. 3c shows that the HCN EFs obtained using the time-based approach exhibit a strong seasonal dependence, with the median summertime $\mathrm{EF}$ almost a factor of 5 higher than the median wintertime EF. This behavior is opposite that of benzene, which has higher wintertime EFs by about a factor of 2 due to enhanced coldstart emissions and changes in gasoline composition (Lough et al., 2005). Although the mechanisms for HCN and benzene 
formation are different (the former involving chemistry on high-temperature catalysts), the reasons for the higher $\mathrm{HCN}$ EFs in the summer are not known.

Early studies on some of the first-generation three-way catalysts yielded very high $\mathrm{HCN}$ emission factors, typically under abnormal or malfunctioning operating conditions (Bradow and Stump, 1977; Keirns and Holt, 1978; Cadle et al., 1979; Urban and Garbe, 1979, 1980). The magnitude of the HCN emissions exhibited high car-to-car variability and a strong dependence on operating conditions, as well as the presence and composition of the catalysts. An average LDGV HCN EF of $12.1 \mathrm{mg} \mathrm{km}^{-1}$ was estimated from a review (Harvey et al., 1983) of these early studies - over 2 orders of magnitude greater than the EFs obtained here. However, those EF estimations were obtained for all driving modes for both normal and abnormal operating conditions.

Given the significant improvements in catalyst and emissions reduction technologies since the 1970s and 1980s, the applicability of these early studies to current HCN emission is questionable. Certainly, more recent studies (Karlsson, 2004; Baum et al., 2006; Becker et al., 1999; Moussa et al., 2016) suggest that present-day HCN EFs are much lower with individual vehicle $\mathrm{EFs}$ ranging from 0 to $11.7 \mathrm{mg} \mathrm{km}^{-1}$ (see Table 4). However, these limited dynamometer studies also reveal a large inter-vehicle variability in HCN EFs, with no clear pattern between emissions and vehicle characteristics (e.g., age). The most recent study (Moussa et al., 2016) also showed that intra-vehicle EFs are highly sensitive to fuel injection technology (e.g., gasoline direct injection, GDI, vs. port-fuel injection, PFI), after-treatment technology (presence and absence of a particulate filter), and operating conditions (e.g., aggressiveness of driving cycle, hot vs. cold starts).

The median winter HCN EF obtained in this study (using either the plume-based or time-based approach) is over 1 order of magnitude lower than the average EF obtained by the most recent dynamometer study (Moussa et al., 2016). The higher summer HCN EF obtained by the time-based analysis is in better agreement, although it is still low. However, due to the aforementioned variability in the dynamometer results, a direct comparison is not straightforward. As with HNCO, our study provides the most comprehensive $\mathrm{HCN}$ emission factors available to date since the mobile design allows us to obtain EFs for a large number of vehicles, thereby capturing the real-world inter- and intra-vehicle variability of emissions. Similarly, the IQR $\left(0.32-0.88 \mathrm{mg} \mathrm{kg}_{\text {fuel }}^{-1}\right)$ and distribution of measured EFs (Fig. 4d) give new insight into the range of on-road $\mathrm{HCN}$ emission factors.

\subsection{Emission factor distributions: contributions from high-emitters}

The spread in the EFs for all measured pollutants is wide, consistent with prior mobile studies (Park et al., 2011; Hudda et al., 2013; Zavala et al., 2009). Such variability is ex-

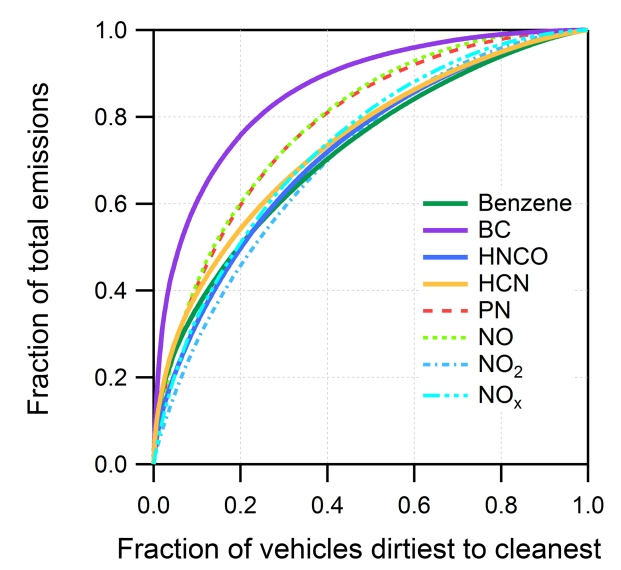

Figure 5. Cumulative emission factor distributions for SPP plumebased measurements: benzene (solid, green), BC (solid, purple), HNCO (solid, blue), HCN (solid, yellow), NO (dotted, light green), $\mathrm{NO}_{2}$ (dotted, light blue), $\mathrm{NO}_{x}$ (dotted, light teal), and particle number (dotted, pink). A one-to-one line would indicate that all vehicles have the same emission factor.

pected given the differences in speed, acceleration, grade, and inter-vehicle variability occurring on-road. As illustrated by Figs. 4 and S5, the EFs are log-normally distributed, with the degree of skewness dependent on pollutant. Skewness in EF distributions is typically attributed to the presence of high-emitting vehicles among the fleet, but may also arise from the range and transient nature of driving conditions experienced in the real world (e.g., hard acceleration). The distributions provide insight into the strategy for emission reductions. From a policy perspective, pollutants exhibiting a more normal distribution may be most effectively targeted by tightening fleet-wide regulations while those exhibiting a more skewed distribution may be most effectively targeted, initially, by the removal of high-emitters (Hudda et al., 2013).

Cumulative emission factor distributions for several pollutants are presented in Fig. 5. These plots highlight the relative skewness of EFs for each pollutant by displaying the fraction of total emissions as a function of the fraction of vehicles, sorted from largest to smallest EF. The distributions are highly skewed for NO and PN and exceptionally skewed for BC, as observed by others (Jiang et al., 2005; Hudda et al., 2013; Liggio et al., 2012). This behavior is expected given that these pollutants are emitted in large quantities from diesel-powered vehicles, which represent a small fraction of the fleet (Jiang et al., 2005; Ban-Weiss et al., 2008, 2010; Jimenez et al., 2000; Dallmann et al., 2012, 2013; Liggio et al., 2012; Wang et al., 2015; Tan et al., 2014) and hence were encountered by CRUISER less often. For NO, it is also likely that an unknown quantity of emitted NO is being converted to $\mathrm{NO}_{2}$ before plume capture (hence the high frequency of EFs in the lowest bin, $<0.15 \mathrm{~g} \mathrm{~kg}_{\text {fuel }}^{-1}$ ), further exacerbating the skewness. For BC, the top $25 \%$ worst emitters, likely all diesel vehicles, contribute to more than $80 \%$ 
Table 4. Comparison of literature HCN emission factors from the exhaust of various gasoline- and diesel-fueled engines in distance-based units $\left(\mathrm{mg} \mathrm{km}^{-1}\right)$. NA stands for "not available".

\begin{tabular}{|c|c|c|c|c|c|}
\hline Reference & Type of study & $\mathrm{HCN}$ detection & $\begin{array}{l}\text { Range/ } \\
\mathrm{mg} \mathrm{km}^{-1}\end{array}$ & $\begin{array}{l}\text { Average/ } \\
\mathrm{mg} \mathrm{km}^{-1}\end{array}$ & Description of vehicles and fuel \\
\hline This study & Mobile & HR-TOF-CIMS & $0.03-0.07^{\mathrm{a}}$ & $\begin{array}{l}0.043,0.068^{b} \\
0.046,0.069 \\
0.21,0.37\end{array}$ & $\begin{array}{l}\text { Winter fleet, plume based (SPP) } \\
\text { Winter fleet, time based (120 s) } \\
\text { Summer fleet, time based (120 s) }\end{array}$ \\
\hline $\begin{array}{l}\text { Bradow and Stump } \\
\text { (1977) }\end{array}$ & $\begin{array}{l}\text { Chassis and } \\
\text { engine } \\
\text { dynamometer }\end{array}$ & $\begin{array}{l}\text { Offline after } \\
\text { trapping by } \mathrm{NaOH}\end{array}$ & $\begin{array}{l}<\text { LOD (normal } \\
\text { operation) } \\
0.0-75.6 \\
\text { (malfunctioning) }\end{array}$ & NA & $\begin{array}{l}3 \text { LDGVs w/ TWC (1977) } \\
5 \text { LDGVs w/o TWC (1976) }\end{array}$ \\
\hline $\begin{array}{l}\text { Keirns and Holt } \\
(1978)\end{array}$ & $\begin{array}{l}\text { Chassis } \\
\text { dynamometer }\end{array}$ & $\begin{array}{l}\text { Offline after } \\
\text { trapping by } \mathrm{NaOH}\end{array}$ & $\begin{array}{l}<1.4 \text { (LOD) (normal } \\
\text { operation) } \\
0.8-11.8 \\
\text { (malfunctioning) }\end{array}$ & NA & $\begin{array}{l}1 \mathrm{LDGV} \text { w/ and w/o TWC of varying } \\
\text { composition (1977) }\end{array}$ \\
\hline Cadle et al. (1979) & $\begin{array}{l}\text { Chassis } \\
\text { dynamometer }\end{array}$ & $\begin{array}{l}\text { Trapping by } \\
\mathrm{NaOH} \text { with } \\
\text { colorimetric } \\
\text { detection }\end{array}$ & $0-14.4$ & $\begin{array}{l}6.9 \text { (no catalyst) } \\
0.6 \text { (oxidation } \\
\text { catalyst) } \\
3.1 \text { (dual or three- } \\
\text { way catalyst) } \\
8.1 \text { (rich } \\
\text { malfunction with } \\
\text { TWC) }\end{array}$ & $\begin{array}{l}26 \text { LDGVs (production and } \\
\text { experimental, 1967-1978) }\end{array}$ \\
\hline $\begin{array}{l}\text { Urban and Garbe } \\
\text { (1979) }\end{array}$ & $\begin{array}{l}\text { Chassis } \\
\text { dynamometer }\end{array}$ & $\begin{array}{l}\text { Trapping by } \\
\mathrm{NaOH}, \mathrm{GC}-\mathrm{ECD}\end{array}$ & $\begin{array}{l}0.0-2.4 \text { (normal) } \\
0.3-2.3 \\
\text { (malfunctioning) }\end{array}$ & $\begin{array}{l}0.2 \text { (normal, } \\
\text { excluding LDV } \\
\text { w/o catalyst) }\end{array}$ & $\begin{array}{l}5 \text { LDGVs (1977-1978), } 1 \text { w/o } \\
\text { catalyst, } 4 \text { w/ oxidation catalyst }\end{array}$ \\
\hline $\begin{array}{l}\text { Urban and Garbe } \\
\text { (1980) }\end{array}$ & $\begin{array}{l}\text { Chassis } \\
\text { dynamometer }\end{array}$ & $\begin{array}{l}\text { Trapping by } \\
\mathrm{NaOH}, \mathrm{GC}-\mathrm{ECD}\end{array}$ & $\begin{array}{l}0.1-1.1 \text { (normal) } \\
0.0-112.3 \\
\text { (malfunctioning) }\end{array}$ & & 4 LDGVs with TWC (1978-1979) \\
\hline Harvey et al. (1983) & Review & NA & $\begin{array}{l}\text { 1.0-12.1 (weighted } \\
\text { normal and } \\
\text { malfunctioning } \\
\text { averages for LDVs } \\
\text { w/ different catalyst } \\
\text { cases) }\end{array}$ & 7.1 & $\begin{array}{l}206 \text { LDVs (non-catalyst, oxidation } \\
\text { catalyst, TWC), } 11 \text { HDVs, gasoline } \\
\text { and diesel }\end{array}$ \\
\hline Becker et al. (1999) & $\begin{array}{l}\text { Chassis } \\
\text { dynamometer }\end{array}$ & FTIR & NA & $<2$ (below LOD) & 21 LDGVs (1996-1997) \\
\hline Karlsson (2004) & $\begin{array}{l}\text { Chassis } \\
\text { dynamometer }\end{array}$ & $\begin{array}{l}\text { Trapping by } \\
\mathrm{NaOH} \text { with } \\
\text { colorimetric } \\
\text { detection }\end{array}$ & $0.0-11.7$ & $2.2 \pm 4.2$ & 5 LDGVs (1989-1998) \\
\hline Moussa et al. (2016) & $\begin{array}{l}\text { Chassis } \\
\text { dynamometer }\end{array}$ & PTR-TOF-MS & $0.0-5.6$ & $1.4 \pm 1.7$ & 3 LDGVs (2008-2011) \\
\hline
\end{tabular}

${ }^{\mathrm{a}}$ Interquartile range; ${ }^{\mathrm{b}}$ median, mean.

of the total emissions, while the top $5 \%$ contribute to almost $50 \%$. At a near-road site in Toronto, the top $25 \%$ worst emitters were found to contribute to $100 \%$ of the total BC emissions, with the top $5 \%$ contributing $>60 \%$ (Wang et al., 2015). As more heavy-duty vehicles become equipped with particulate filters and advanced $\mathrm{NO}_{x}$ abatement technologies (i.e., SCR systems) the overall $\mathrm{EF}$ distributions for pollutants such as BC and NO may shift, but the skewness could actually increase unless high-emitters, such as the older, legacy diesel vehicles, are specifically targeted (McDonald et al., 2013).

The EF distributions for the VOCs were less skewed (Jiang et al., 2005; Hudda et al., 2013; Wang et al., 2015). The benzene, HNCO, and HCN profiles in Fig. 5 are similar, with the top $25 \%$ worst emitters contributing $55 \%-60 \%$ of the total emissions and the top 5\% contributing $20 \%-30 \%$. The less skewed distributions for $\mathrm{HNCO}$ and $\mathrm{HCN}$ may indicate that their HDDV EFs are not significantly higher than their 
Table 5. Annual traffic pollutant emissions from the transportation sector and biomass burning for Canada and Ontario.

\begin{tabular}{|c|c|c|c|c|c|c|}
\hline & & $\mathrm{NO}_{x}$ & Benzene & $\mathrm{BC}$ & HNCO & $\mathrm{HCN}$ \\
\hline \multirow[t]{2}{*}{ Canada 2015} & Vehicle emissions ${ }^{\mathrm{a}}(\mathrm{t})$ & $1.05 \times 10^{5}$ & 2180 & 1150 & \multirow{2}{*}{$\begin{array}{l}104 \\
5377^{\mathrm{c}}\end{array}$} & \multirow{2}{*}{$\begin{array}{l}24 \\
\left(1.2^{\mathrm{d}}-5.8^{\mathrm{e}}\right) \times 10^{4}\end{array}$} \\
\hline & $\begin{array}{l}\text { Forest fires }^{\mathrm{b}}(\mathrm{t}) \\
\text { Vehicle emissions inventory } \\
\text { estimates }(\mathrm{t})\end{array}$ & $4.26 \times 10^{5 f}$ & $6600^{\mathrm{g}}$ & $6401^{\mathrm{h}}$ & & \\
\hline \multirow[t]{2}{*}{ Ontario 2015} & Vehicle emissions $^{\mathrm{a}}(\mathrm{t})$ & $5.29 \times 10^{4}$ & 775 & 409 & 37 & 9 \\
\hline & Forest fires ${ }^{b}(t)$ & & & & $40^{\mathrm{c}}$ & $87^{\mathrm{d}}-431^{\mathrm{e}}$ \\
\hline
\end{tabular}

${ }^{\mathrm{a}}$ In 2015, net sales for gasoline and diesel in Canada were $4.26 \times 10^{10}$ and $1.80 \times 10^{10} \mathrm{~L}$ respectively (Statistics Canada, 2016). The total mass of fuel is calculated assuming a fuel density at $15^{\circ} \mathrm{C}$ of 730 and $840 \mathrm{~kg} \mathrm{~m}^{-3}$ for gasoline and diesel respectively, for a nationwide total of $4.62 \times 10^{7} \mathrm{t}$ of fuel. In 2015, net sales of gasoline and diesel in Ontario were $1.63 \times 10^{10}$ and $5.43 \times 10^{9} \mathrm{~L}$ respectively, for a provincial total of $1.64 \times 10^{7} \mathrm{t}$ (Statistics Canada, 2016). Vehicle emissions were calculated using the plume-based SPP emission factors. ${ }^{b}$ Wildfire CO emissions were calculated to be 5003 and $37.3 \mathrm{kt}$ for Canada and Ontario respectively. ${ }^{\mathrm{c}} \mathrm{HNCO}$ emission calculated using $\mathrm{HNCO} / \mathrm{CO}$ emission ratio (ER) for oak woodlands of $0.7 \mathrm{mmol} \mathrm{HNCO} \mathrm{mol} \mathrm{CO}{ }^{-1}$ (Veres et al., 2010). ${ }^{\mathrm{d}} \mathrm{HCN}$ emission calculated using $\mathrm{HNCO} / \mathrm{CO} \mathrm{ER}$ of $0.00242 \mathrm{~mol} \mathrm{HCN} \mathrm{mol} \mathrm{CO}^{-1}$ (Rinsland et al., 2007). ${ }^{\mathrm{e}} \mathrm{HCN}$ emission calculated using $\mathrm{HNCO} / \mathrm{CO}$ ER of $0.012 \mathrm{~mol} \mathrm{HCN} \mathrm{mol} \mathrm{CO}^{-1}$ (Akagi et al., 2011). ${ }^{\mathrm{f}}$ Estimated $\mathrm{NO}_{x}$ emissions for 2015 from light- and heavy-duty diesel and gasoline vehicles, trucks, and motorcycles (Air Pollution Emission Inventory, 2018). ${ }^{\mathrm{g}}$ Estimated on-road transportation benzene emissions for 2008 (Canada-Wide Standard for Benzene: 2010 Final Report). ${ }^{\mathrm{h}}$ Estimated BC emissions for 2015 from diesel (5679 t) and gasoline (722 t) on-road vehicles (Canada's Black Carbon Inventory: 2017 Edition).

corresponding LDGV EFs. The least skewed pollutant in this study is $\mathrm{NO}_{2}$ - the top $25 \%$ worst emitters only contribute to $\sim 50 \%$ of total emissions and the top $5 \%$ contribute to $\sim 15 \%$. As suggested above, post-tailpipe conversion of NO to $\mathrm{NO}_{2}$ is likely occurring prior to measurement. The cumulative emission factor distribution for $\mathrm{NO}_{x}\left(=\mathrm{NO}+\mathrm{NO}_{2}\right)$ more closely resembles the distribution for VOCs and $\mathrm{NO}_{2}$ than NO.

\subsection{Vehicle emission estimates for Canada}

Annual emissions for Ontario and Canada can be estimated using the fuel-based EFs and from annual sales of gasoline and diesel. The assumption here is that the gasoline and diesel sales are proportional to the number of gasoline- and diesel-powered vehicles on the road and that the EFs obtained from the mobile measurements reflect this distribution. A summary of total vehicle emissions of $\mathrm{NO}_{x}$, benzene, $\mathrm{BC}, \mathrm{HNCO}$, and $\mathrm{HCN}$ calculated using the median plume-based emission factors is given in Table 5. Nationwide inventory estimates for $\mathrm{NO}_{x}$ (Air Pollutants Emissions Inventory, 2015), benzene (CCME, 2012), and BC emissions (ECC, 2017) by the transportation sector are also listed in Table 5 for comparison. For all three pollutants, the scaled-up emissions were more than a factor of 2 lower than the inventory estimates. Using the mean EFs rather than median reduces this discrepancy. Our results suggest that the inventories may be overestimated but more work is required to understand the reasons for the difference.

We estimate that on a national scale, $104 \mathrm{t}$ of $\mathrm{HNCO}$ and $24 \mathrm{t}$ of HCN are emitted annually by on-road vehicles. These values are lower than the recent nationwide estimates of 250-770 t HNCO for 2010 (Wentzell et al., 2013) and $703 \mathrm{t} \mathrm{HCN}$ for 2012 (Moussa et al., 2016), owing to the lower fleet-average EFs obtained in this study. These vehicle emissions can be placed in the context of their respective biomass burning emissions. Total wildfire emissions of $\mathrm{CO}$ during the 2015 wildfire season (31 May-2 November 2015) were calculated using FireWork-GEM-MACH (Pavlovic et al., 2016). These total CO emissions were then scaled by literature emission ratios (ER) expressed as mole of pollutant per mole of $\mathrm{CO}$ to estimate biomass burning emissions (Table 5). Only a few studies have investigated HNCO ERs (Veres et al., 2010; Roberts et al., 2011). Biomass burning emissions of HCN have been the subject of a greater number of studies, but a recent review notes that the HCN/CO ER can be different for different fire types and that even within single or similar fire types there is a high variability in $\mathrm{HCN}$ emissions (Akagi et al., 2011).

In 2015, HNCO emissions from forest fires were estimated at 5377 and $40 \mathrm{t}$ for Canada and Ontario respectively. Although on a national scale the HNCO vehicle emissions are over 1 order of magnitude lower than the biomass burning emissions, in urban areas the vehicle source becomes relatively more significant. This is seen in the provincial comparison, where the greater population density and lower frequency of forest fires in Ontario results in HNCO vehicle emissions comparable in magnitude to biomass burning emissions. When secondary formation of HNCO from precursors in vehicle exhaust is also taken into account (Link et al., 2016; Liggio et al., 2017b), the significance of vehicle emissions as a source of HNCO will likely be further enhanced.

In 2015, the HCN emissions from forest fires were estimated at (1.2-5.8) $\times 10^{4}$ and (87-431) $t$ for Canada and Ontario respectively. At the national scale, the biomass burning emissions are about 3 orders of magnitude greater than the vehicle emissions. Even at the provincial scale, the biomass burning emissions are about 1 order of magnitude greater than the vehicle emissions. This result is consistent with the large BKG component to the ambient measurements made 
in the study. If the summertime EF obtained using the timebased approach is used $\left(2.7 \mathrm{mg} \mathrm{kg}_{\text {fuel }}^{-1}\right)$ then the total vehicle emissions of $\mathrm{HCN}$ are estimated at 125 and $44 \mathrm{t}$ for Canada and Ontario respectively, still lower than previous estimates (Moussa et al., 2016). Although biomass burning emissions continue to be the dominant source of $\mathrm{HCN}$ in this estimation, the potential significance of vehicles as a source of $\mathrm{HCN}$, especially in urban areas with minimal BB influence, is non-negligible.

\section{Conclusions and implications}

We deployed a mobile laboratory over a large metropolitan area, capturing exhaust emissions from a large number of vehicles under a range of operating conditions and driving environments. Plume-based and time-based algorithms were developed to estimate EFs from the on-road measurements. The plume-based method avoids cumbersome crossreference with recorded vehicle plumes (i.e., as in "vehicle chase" methods) and shows potential for obtaining realworld EFs from limited-term mobile studies with minimal computational effort. The time-based method was found to perform well for pollutants with less skewed EF distributions (i.e., not associated with high HDDV emissions) and best for pollutants with minimal local sources (i.e., HNCO and $\mathrm{HCN}$ ). Further studies are required to fully validate the time-based method, but this approach could potentially be used to calculate EFs from near-road sites with lower-timeresolution datasets. Both methodologies could thus be efficient ways of rapidly monitoring trends in emission factors, especially for pollutants whose emissions are likely to be influenced by emerging technologies or policies. Hence, this approach could be valuable for documenting accountability.

Based on good agreement of the plume-based EFs with reported literature EFs for common traffic pollutants, and the more precise definition of vehicle exhaust for this methodology, the plume-based EFs are considered to be superior to the time-based EFs. Due to the broad range of vehicles and real-world conditions captured by the measurements, the plume-based algorithm applied to mobile measurements provides a better average $\mathrm{EF}$ for use in scaling up emissions or for assessing general exposure than a limited number of dynamometer studies. We thereby obtain the first and most representative fleet-average emission factors for $\mathrm{HNCO}$ and $\mathrm{HCN}$, as well as insight into their real-world variability.

The plume-based EF obtained for black carbon in this study (median: $25 \mathrm{mg} \mathrm{kg}_{\text {fuel }}^{-1}$, IQR: $10-76 \mathrm{mg} \mathrm{kg}_{\text {fuel }}^{-1}$ ) is consistent with decreases in vehicular BC emissions over time (Ban-Weiss et al., 2008; Dallmann et al., 2013). Despite this improvement, our work, like that of others, shows that a small number of vehicles (predominantly HDDV) are responsible for a disproportionate amount of the on-road $\mathrm{BC}$ emissions. As a result, $\mathrm{BC}$ concentrations, and hence exposure, are highest near highways and major roadways, and efforts to target these emissions will likely have a strong impact on local air quality. In North America, GDI vehicles are replacing PFI vehicles, which currently dominate the light-duty fleet (Chan et al., 2014). GDI vehicles promise advantages such as lower fuel consumption but have been shown in recent studies to emit more BC than their PFI counterparts (Saliba et al., 2017) - although introduction of gasoline particulate filters could mitigate this effect (Chan et al., 2014; Saliba et al., 2017). Future decreases in diesel emission of $\mathrm{BC}$ are also predicted (Dallmann et al., 2012) as the fleet turns over and more diesel trucks on the road are equipped with diesel particulate filters. Therefore, it is critical that fleet emissions of $\mathrm{BC}$ are monitored in the future, with careful attention to the relative contributions from heavy-duty vs. light-duty vehicles. Since BC also impacts global climate change (Highwood and Kinnersley, 2006; Bond et al., 2013), mitigating vehicle emissions of $\mathrm{BC}$ has the dual benefit of meeting air pollution and climate targets (Bahadur et al., 2011; Bond et al., 2013).

Overall, our results indicate that a vehicle fleet dominated by light-duty gasoline vehicles is a source of HNCO and $\mathrm{HCN}$ to the atmosphere, with plume-based median EFs under wintertime, real-world, driving conditions of $2.3 \mathrm{mg} \mathrm{kg}_{\text {fuel }}^{-1}$ (IQR: $1.4-4.2 \mathrm{~m} \mathrm{~kg} \mathrm{fuel}_{\text {fue }}^{-1}$ ) and $0.52 \mathrm{mg} \mathrm{kg}_{\text {fuel }}^{-1}$ (IQR: $0.32-$ $0.88 \mathrm{mg} \mathrm{kg}_{\text {fuel }}^{-1}$ ) respectively. Given our poor understanding of how emerging emission control technologies (e.g., SCR systems, diesel oxidation catalysts) influence $\mathrm{HNCO}$ emissions, it is imperative that fleet emissions of HNCO are studied over time. The impact of vehicle emissions on secondary $\mathrm{HNCO}$ production in urban areas should also be investigated.

Our work demonstrates that $\mathrm{HCN}$ emission factors obtained in outdated dynamometer studies for LDGVs equipped with first-generation three-way catalysts under abnormal operating conditions (Harvey et al., 1983) are not applicable to the present day. However, they indicate that the most recent dynamometer studies (Moussa et al., 2016; Karlsson, 2004) may also overestimate real-world HCN emissions. Overall, the relatively small vehicle emission factor obtained in this study suggests that vehicles are not likely a significant source of $\mathrm{HCN}$ on a regional and larger scale. However, in view of the discrepancies between this study and others (Moussa et al., 2016), and the paucity of HCN measurements in urban locations, more work is required to establish the atmospheric significance of vehicle emissions of $\mathrm{HCN}$ at the neighborhood and smaller scale. In particular, the extent and cause of variation in $\mathrm{HCN}$ concentrations and emission factors, which appear to vary widely in ambient measurements and dynamometer studies respectively, should be further constrained and understood. Future research should also seek to understand the reasons for the observed seasonal variation in $\mathrm{HCN}$ concentrations and emission factors. 
Data availability. The underlying mobile data (HNCO, HCN, black carbon, $\mathrm{VOC}, \mathrm{NO}_{2}, \mathrm{NO}, \mathrm{CO}_{2}, \mathrm{PN}$, metadata) for the summer and winter campaigns are available at the Pan Am 2015 study site (Government of Canada, 2018, https://open.canada.ca/data/en/ dataset/1260ee96-7acf-489e-826b-de96f0c19fcb). The complete output of the plume-based and time-based EF algorithms and other related data are available at the request of the corresponding authors.

Supplement. The supplement related to this article is available online at: https://doi.org/10.5194/acp-18-16979-2018-supplement.

Author contributions. JRB, JL, KH, and CS were responsible for the planning, execution, and oversight of the mobile studies. JL and JJBW obtained the HNCO and HCN data. GL obtained the BC and PN data. RLM obtained the $\mathrm{CO}_{2}$ data. SNW and $\mathrm{YH}$ obtained the VOC data. SNW and YH obtained the NO data. CMM obtained the $\mathrm{NO}_{2}$ data. JL and SNW developed the algorithms and conceptualized the present study. SNW performed the calculations and analysis with input from JL and JRB. SNW prepared the paper with comments from all authors.

Competing interests. The authors declare that they have no conflict of interest.

Acknowledgements. We thank the technical support staff and information management/information technology team of AQRD for assistance with equipment and data system installation, data management, and driving. We thank Amy Leithead for assistance with the PTR-TOF-MS and Junhua Zhang for providing the wildfire $\mathrm{CO}$ estimates from Firework-GEM-MACH. This program was supported by the Clean Air Regulatory Agenda (CARA).

Edited by: James Roberts

Reviewed by: two anonymous referees

\section{References}

Air Pollutants Emission Inventory: Air Pollutants Emission Inventory online search, available at: https://pollution-waste.canada. ca/air-emission-inventory (last access: 18 April 2018), 2015.

Akagi, S. K., Yokelson, R. J., Wiedinmyer, C., Alvarado, M. J., Reid, J. S., Karl, T., Crounse, J. D., and Wennberg, P. O.: Emission factors for open and domestic biomass burning for use in atmospheric models, Atmos. Chem. Phys., 11, 4039-4072, https://doi.org/10.5194/acp-11-4039-2011, 2011.

Ambrose, J. L., Haase, K., Russo, R. S., Zhou, Y., White, M. L., Frinak, E. K., Jordan, C., Mayne, H. R., Talbot, R., and Sive, B. C.: A comparison of GC-FID and PTR-MS toluene measurements in ambient air under conditions of enhanced monoterpene loading, Atmos. Meas. Tech., 3, 959-980, https://doi.org/10.5194/amt-3-959-2010, 2010.
Ambrose, J. L., Zhou, Y., Haase, K., Mayne, H. R., Talbot, R., and Sive, B. C.: A gas chromatographic instrument for measurement of hydrogen cyanide in the lower atmosphere, Atmos. Meas. Tech., 5, 1229-1240, https://doi.org/10.5194/amt-5-1229-2012, 2012.

Araizaga, A. E., Mancilla, Y., and Mendoza, A.: Volatile organic compound emissions from light-duty vehicles in Monterrey, Mexico: a tunnel study, Int. J. Environ. Res., 7, 277-292, 2013.

Bahadur, R., Feng, Y., Russell, L. M., and Ramanathan, V.: Impact of California's air pollution laws on black carbon and their implications for direct radiative forcing, Atmos. Environ., 45, 11621167, 2011.

Ban-Weiss, G. A., McLaughlin, J. P., Harley, R. A., Lunden, M. M., Kirchstetter, T. W., Kean, A. J., Strawa, A. W., Stevenson, E. D., and Kendall, G. R.: Long-term changes in emissions of nitrogen oxides and particulate matter from on-road gasoline and diesel vehicles, Atmos. Environ., 42, 220-232, 2008.

Ban-Weiss, G. A., Lunden, M. M., Kirchstetter, T. W., and Harley, R. A.: Size-resolved particle number and volume emission factors for on-road gasoline and diesel motor vehicles, J. Aerosol Sci., 41, 5-12, 2010.

Barillo, D. J.: Diagnosis and treatment of cyanide toxicity, J. Burn Care Res., 30, 148-152, 2009.

Barth, M. C., Cochran, A. K., Fiddler, M. N., Roberts, J. M., and Bililign, S.: Numerical modeling of cloud chemistry effects on isocyanic acid (HNCO), J. Geophys. Res.-Atmos., 118, 86888701, 2013.

Baum, M. M., Moss, J. A., Pastel, S. H., and Poskrebyshev, G. A.: Hydrogen cyanide exhaust emissions from in-use motor vehicles, Environ. Sci. Technol., 41, 857-862, 2006.

Becker, K. H., Lörzer, Kurtenbach, R., Wiesen, P., Jensen, T. E., and Wallington, T. J.: Nitrous oxide $\left(\mathrm{N}_{2} \mathrm{O}\right)$ emissions from vehicles, Environ. Sci. Technol., 33, 4134-4139, 1999.

Beckerman, B., Jerrett, M., Brook, J. R., Verma, D. K., Arain, M. A., and Finkelstein, M. M.: Correlation of nitrogen dioxide with other traffic pollutants near a major expressway, Atmos. Environ., 42, 275-290, 2008.

Bishop, G. A. and Stedman, D. H.: A decade of on-road emissions measurements, Environ. Sci. Technol., 42, 1651-1656, 2008.

Bond, T. C., Doherty, S. J., Fahey, D. W., Forster, P. M., Berntsen, T., DeAngelo, B. J., Flanner, M. G., Ghan, S., Kärcher, B., Koch, D., Kinne, S., Kondo, Y., Quinn, P. K., Sarofim, M. C., Schultz, M. G., Schulz, M., Venkataraman, C., Zhang, H., Zhang, S., Bellouin, N., Guttikunda, S. K., Hopke, P. K., Jacobson, M. Z., Kaiser, J. W., Klimont, Z., Lohmann, U., Schwarz, J. P., Shindell, D., Storelvmo, T., Warren, S. G., and Zender, C. S.: Bounding the role of black carbon in the climate system: A scientific assessment, J. Geophys. Res.-Atmos., 118, 5380-5552, 2013.

Borduas, N., Abbatt, J. P., and Murphy, J. G.: Gas phase oxidation of monoethanolamine (MEA) with $\mathrm{OH}$ radical and ozone: kinetics, products, and particles, Environ. Sci. Technol., 47, 6377-6383, 2013.

Borduas, N., da Silva, G., Murphy, J. G., and Abbatt, J. P.: Experimental and theoretical understanding of the gas phase oxidation of atmospheric amides with $\mathrm{OH}$ radicals: kinetics, products, and mechanisms, J. Phys. Chem. A, 119, 4298-4308, 2015.

Borduas, N., Place, B., Wentworth, G. R., Abbatt, J. P. D., and Murphy, J. G.: Solubility and reactivity of HNCO in water: insights 
into HNCO's fate in the atmosphere, Atmos. Chem. Phys., 16, 703-714, https://doi.org/10.5194/acp-16-703-2016, 2016.

Bradow, R. L. and Stump, F. D.: Unregulated emissions from three-way catalyst cars, SAE Tech. Pap. Ser., 770369, 7703, https://doi.org/10.4271/770369, 1977.

Brady, J. M., Crisp, T. A., Collier, S., Kuwayama, T., Forestieri, S. D., Perraud, V., Zhang, Q., Kleeman, M. J., Cappa, C. D., and Bertram, T. H.: Real-time emission factor measurements of isocyanic acid from light duty gasoline vehicles, Environ. Sci. Technol., 48, 11405-11412, 2014.

Brook, J. R., Burnett, R. T., Dann, T. F., Cakmak, S., Goldberg, M. S., Fan, X., and Wheeler, A. J.: Further interpretation of the acute effect of nitrogen dioxide observed in Canadian time-series studies, J. Exp. Sci. Environ. Epidemiol., 17, S36, https://doi.org/10.1038/sj.jes.7500626, 2007.

Bukowiecki, N., Dommen, J., Prévôt, A. S. H., Richter, R., Weingartner, E., and Baltensperger, U.: A mobile pollutant measurement laboratory - measuring gas phase and aerosol ambient concentrations with high spatial and temporal resolution, Atmos. Environ., 36, 5569-5579, 2002.

Cadle, S. H., Nebel, G. J., and Williams, R. L.: Measurements of unregulated emissions from General Motors' light-duty vehicles, SAE Tech. Pap. Ser., 790694, 7906, https://doi.org/10.4271/790694, 1979.

Canagaratna, M. R., Jayne, J. T., Ghertner, D. A., Herndon, S., Shi, Q., Jimenez, J. L., Silva, P. J., Williams, P., Lanni, T., Drewnick, F., Demerjian, K. L., Kolb, C. E., and Worsnop, D. R.: Chase studies of particulate emissions from in-use New York City vehicles, Aerosol Sci. Tech., 38, 555-573, 2004.

CCME - Canadian Council of Ministers of the Environment: Canada-Wide Standard for Benzene: 2010 Final Report, January 2012, CCME, Winnipeg, Canada, 12 pp., 2012.

Chan, T. W., Brook, J. R., Smallwood, G. J., and Lu, G.: Time-resolved measurements of black carbon light absorption enhancement in urban and near-urban locations of southern Ontario, Canada, Atmos. Chem. Phys., 11, 10407-10432, https://doi.org/10.5194/acp-11-10407-2011, 2011.

Chan, T. W., Meloche, E., Kubsh, J., and Brezny, R.: Black Carbon Emissions in Gasoline Exhaust and a Reduction Alternative with a Gasoline Particulate Filter, Environ. Sci. Technol., 48, 60276034, 2014.

Chandra, B. P. and Sinha, V.: Contribution of post-harvest agricultural paddy residue fires in the N.W. Indo-Gangetic Plain to ambient carcinogenic benzenoids, toxic isocyanic acid and carbon monoxide, Environ. Int., 88, 187-197, 2016.

Choi, M. Y., Hamins, A., Mulholland, G. W., and Kashiwagi, T.: Simultaneous optical measurement of soot volume fraction and temperature in premixed flames, Combust. Flame, 99, 174-186, 1994.

Coderre, A. R., Thomson, K. A., Snelling, D. R., and Johnson, M. R.: Spectrally resolved light absorption properties of cooled soot from a methane flame, Appl. Phys. B, 104, 175-188, 2011.

Coggon, M. M., Veres, P. R., Yuan, B., Koss, A., Warneke, C., Gilman, J. B., Lerner, B. M., Peischl, J., Aikin, K. C., Stockwell, C. E., Hatch, L. E., Ryerson, T. B., Roberts, J. M., Yokelson, R. J., de Gouw, J. A.: Emissions of nitrogen-containing organic compounds from the burning of herbaceous and arboraceous biomass: Fuel composition dependence and the variability of commonly used nitrile tracers, Geophys. Res. Lett., 43, 9903 9912, 1016.

Crounse, J. D., DeCarlo, P. F., Blake, D. R., Emmons, L. K., Campos, T. L., Apel, E. C., Clarke, A. D., Weinheimer, A. J., McCabe, D. C., Yokelson, R. J., Jimenez, J. L., and Wennberg, P. O.: Biomass burning and urban air pollution over the Central Mexican Plateau, Atmos. Chem. Phys., 9, 4929-4944, https://doi.org/10.5194/acp-9-4929-2009, 2009.

Dallmann, T. R., DeMartini, S. J., Kirchstetter, T. W., Herndon, S. C., Onasch, T. B., Wood, E. C., and Harley, R. A.: On-road measurement of gas and particle phase pollutant emission factors for individual heavy-duty diesel trucks, Environ. Sci. Technol., 46, 8511-8518, 2012.

Dallmann, T. R., Kirchstetter, T. W., DeMartini, S. J., and Harley, R. A.: Quantifying on-road emissions from gasoline-powered motor vehicles: Accounting for the presence of medium- and heavyduty diesel trucks, Environ. Sci. Technol., 47, 13873-13881, 2013.

Dominici, F., Peng, R. D., Barr, C. D., and Bell, M. L.: Protecting human health from air pollution: Shifting from a single-pollutant to a multi-pollutant approach, Epidemiology, 21, 187-194, 2010.

ECCC - Environment and Climate Change Canada: Canada's Black Carbon Inventory: 2017 Edition, ECCC, Canada, 29 pp., 2017.

Franco, V., Kousoulidou, M., Muntean, M., Ntziachristos, L., Hausberger, S., and Dilara, P.: Road vehicle emission factors development: A review, Atmos. Environ., 70, 84-97, 2013.

Gentner, D. R., Worton, D. R., Isaacman, G., Davis, L. C., Dallmann, T. R., Wood, E. C., Herndon, S. C., Goldstein, A. H., and Harley, R. A.: Chemical composition of gas-phase organic carbon emissions from motor vehicles and implications for ozone production, Environ. Sci. Technol., 47, 11837-11848, 2013.

Grahame, T. J., Klemm, R., and Schlesinger, R. B.: Public health and components of particulate matter: The changing assessment of black carbon, J. Air Waste Manage. Assoc., 64, 620-660, 2014.

Government of Canada: Pan Am 2016 Study, available at: https://open.canada.ca/data/en/dataset/ 1260ee96-7acf-489e-826b-de96f0c19fcb, last access: 20 November 2018 .

Harvey, C. A., Garbe, R. J., Baines, T. M., Somers, J. H., Hellman, K. H., and Carey, P. M.: A study of the potential impact of some unregulated motor vehicle emissions, SAE Tech. Pap. Ser., 830987, 8309, https://doi.org/10.4271/830987, 1983.

Heeb, N. V., Zimmerli, Y., Czerwinski, J., Schmid, P., Zennegg, M., Haag, R., Seiler, C., Wichser, A., Ulrich, A., Honegger, P., Zeyer, K., Emmenegger, L., Mosimann, T., Kasper, M., and Mayer, A.: Reactive nitrogen compounds (RNCs) in exhaust of advanced $\mathrm{PM}-\mathrm{NO}_{x}$ abatement technologies for future diesel applications, Atmos. Environ., 45, 3203-3209, 2011.

Heeb, N. V., Haag, R., Seiler, C., Schmid, P., Zennegg, M., Wichser, A., Ulrich, A., Honegger, P., Zeyer, K., Emmenegger, L., Zimmerli, Y., Czerwinski, J., Kasper, M., and Mayer, A.: Effects of a combined Diesel particle filter-DeNOx system (DPN) on reactive nitrogen compounds emissions: a parameter study, Environ. Sci. Technol., 46, 13317-13325, 2012.

HEI Panel on the Health Effects of Traffic-Related Air Pollution: Traffic-related air pollution: A critical review of the literature on emissions, exposure, and health effects, HEI Special Report 17, Health Effects Institute, Boston, MA, 386 pp., 2010. 
Highwood, E. J. and Kinnersley, R. P.: When smoke gets in our eyes: The multiple impacts of atmospheric black carbon on climate, air quality and health, Environ. Int., 32, 560-566, 2006.

Ho, K. F., Lee, S. C., Ho, W. K., Blake, D. R., Cheng, Y., Li, Y. S., Ho, S. S. H., Fung, K., Louie, P. K. K., and Park, D.: Vehicular emission of volatile organic compounds (VOCs) from a tunnel study in Hong Kong, Atmos. Chem. Phys., 9, 7491-7504, https://doi.org/10.5194/acp-9-7491-2009, 2009.

Hudda, N., Fruin, S., Delfino, R. J., and Sioutas, C.: Efficient determination of vehicle emission factors by fuel use category using on-road measurements: downward trends on Los Angeles freight corridor I-710, Atmos. Chem. Phys., 13, 347-357, https://doi.org/10.5194/acp-13-347-2013, 2013.

Hwa, M.-Y., Hsieh, C.-C., Wu, T.-C., and Chang, L.-F. W.: Realworld vehicle emissions and VOCs profile in the Taipei tunnel located at Taiwan Taipei area, Atmos. Environ., 36, 1993-2002, 2002.

Janssen, N. A., Hoek, G., Simic-Lawson, M., Fischer, P., van Bree, L., ten Brink, H., Keuken, M., Atkinson, R. W., Anderson, H. R., Brunekreef, B., and Cassee, F. R.: Black carbon as an additional indicator of the adverse health effects of airborne particles compared with $\mathrm{PM}_{10}$ and $\mathrm{PM}_{2.5}$, Environ. Health Perspect., 119, 1691-1699, 2011.

Jathar, S. H., Heppding, C., Link, M. F., Farmer, D. K., Akherati, A., Kleeman, M. J., de Gouw, J. A., Veres, P. R., and Roberts, J. M.: Investigating diesel engines as an atmospheric source of isocyanic acid in urban areas, Atmos. Chem. Phys., 17, 89598970, https://doi.org/10.5194/acp-17-8959-2017, 2017.

Jerrett, M., Finkelstein, M. M., Brook, J. R., Arain, M. A., Kanaroglou, P., Stieb, D. M., Gilbert, N. L., Verma, D., Finkelstein, N., and Chapman, K. R.: A cohort study of traffic-related air pollution and mortality in Toronto, Ontario, Canada, Environ. Health Perspect., 117, 772-777, 2009.

Jiang, M., Marr, L. C., Dunlea, E. J., Herndon, S. C., Jayne, J. T., Kolb, C. E., Knighton, W. B., Rogers, T. M., Zavala, M., Molina, L. T., and Molina, M. J.: Vehicle fleet emissions of black carbon, polycyclic aromatic hydrocarbons, and other pollutants measured by a mobile laboratory in Mexico City, Atmos. Chem. Phys., 5, 3377-3387, https://doi.org/10.5194/acp-5-3377-2005, 2005.

Jimenez, J. L., McRae, G. J., Nelson, D. D., Zahniser, M. S., and Kolb, C. E.: Remote sensing of $\mathrm{NO}$ and $\mathrm{NO}_{2}$ emissions from heavy-duty diesel trucks using tunable diode lasers, Environ. Sci. Technol., 34, 2380-2387, 2000.

Joe, P., Belair, S., Bernier, N. B., Bouchet, V., Brook, J. R., Brunet, D., Burrows, W., Charland, J. P., Dehghan, A., Driedger, N., Duhaime, C., Evans, G., Filion, A.-B., Frenette, R., Grandpré, J. d., Gultepe, I., Henderson, D., Herdt, A., Hilker, N., Huang, L., Hung, E., Isaac, G., Jeong, C.-H., Johnston, D., Klaassen, J., Leroyer, S., Lin, H., MacDonald, M., MacPhee, J., Mariani, Z., Munoz, T., Reid, J., Robichaud, A., Rochon, Y., Shairsingh, K., Sills, D., Spacek, L., Stroud, C., Su, Y., Taylor, N., Vanos, J., Voogt, J., Wang, J. M., Wiechers, T., Wren, S., Yang, H., and Yip, T.: The Environment and Canada Pan and ParaPan American Science Showcase Project, B. Am. Meteorol. Soc., 99, 921953, https://doi.org/10.1175/BAMS-D-16-0162.1, 2018.

Jordan, A., Haidacher, S., Hanel, G., Hartungen, E., Märk, L., Seehauser, H., Schottkowsky, R., Sulzer, P., and Märk, T. D.: A high resolution and high sensitivity proton-transfer-reaction time-of- flight mass spectrometer (PTR-TOF-MS), Int. J. Mass Spectrom., 286, 122-128, 2009.

Karlsson, H. L.: Ammonia, nitrous oxide and hydrogen cyanide emissions from five passenger vehicles, Sci. Total Environ., 334335, 125-132, 2004.

Keirns, M. H. and Holt, E. L.: Hydrogen cyanide emissions from three-way catalyst prototypes under malfunctioning conditions, SAE Tech. Pap. Ser., 780201, https://doi.org/10.4271/780201, 1978.

Kirchstetter, T. W., Harley, R. A., Kreisberg, N. M., Stolzenburg, M. R., and Hering, S. V.: On-road measurement of fine particle and nitrogen oxide emissions from light- and heavy-duty motor vehicles, Atmos. Environ., 33, 2955-2968, 1999.

Knighton, W. B., Fortner, E. C., Midey, A. J., Viggiano, A. A., Herndon, S. C., Wood, E. C., and Kolb, C. E.: HCN detection with a proton transfer reaction mass spectrometer, Int. J. Mass Spectrom., 283, 112-121, 2009.

Knox, A., Evans, G. J., Brook, J. R., Yao, X., Jeong, C. H., Godri, K. J., Sabaliauskas, K., and Slowik, J. G.: Mass absorption crosssection of ambient black carbon aerosol in relation to chemical age, Aerosol Sci. Tech., 43, 522-532, 2009.

Krecl, P., Johansson, C., Targino, A. C., Ström, J., and Burman, L.: Trends in black carbon and size-resolved particle number concentrations and vehicle emission factors under real-world conditions, Atmos. Environ., 165, 155-168, 2017.

Kristensson, A., Johansson, C., Westerholm, R., Swietlicki, E., Gidhagen, L., Wideqvist, U., and Vesely, V.: Real-world traffic emission factors of gases and particles measured in a road tunnel in Stockholm, Sweden, Atmos. Environ., 38, 657-673, 2004.

Kröcher, O., Elsener, M., and Koebel, M.: An ammonia and isocyanic acid measuring method for soot containing exhaust gases, Anal. Chim. Acta, 537, 393-400, 2005.

Kumar, V., Chandra B. P., Sinha, V.: Large unexplained suite of chemically reactive compounds present in ambient air due to biomass fires, Sci. Rep., 8, 626, https://doi.org/10.1038/s41598017-19139-3, 2018.

Larson, T., Gould, T., Riley, E. A., Austin, E., Fintzi, J., Sheppard, L., Yost, M., and Simpson, C.: Ambient air quality measurements from a continuously moving mobile platform: Estimation of area-wide, fuel-based, mobile source emission factors using absolute principal component scores, Atmos. Environ., 152, 201211, 2017.

Le Breton, M., Bacak, A., Muller, J. B. A., O’Shea, S. J., Xiao, P., Ashfold, M. N. R., Cooke, M. C., Batt, R., Shallcross, D. E., Oram, D. E., Forster, G., Bauguitte, S. J.-B., Palmer, P. I., Parrington, M., Lewis, A. C., Lee, J. D., and Percival, C. $\mathrm{J}$.: Airborne hydrogen cyanide measurements using a chemical ionisation mass spectrometer for the plume identification of biomass burning forest fires, Atmos. Chem. Phys., 13, 92179232, https://doi.org/10.5194/acp-13-9217-2013, 2013.

Levy, I., Mihele, C., Lu, G., Narayan, J., Hilker, N., and Brook, J. R.: Elucidating multipollutant exposure across a complex metropolitan area by systematic deployment of a mobile laboratory, Atmos. Chem. Phys., 14, 7173-7193, https://doi.org/10.5194/acp-14-7173-2014, 2014.

Li, Q., Jacob, D. J., Bey, I., Yantosca, R. M., Zhao, Y., Kondo, Y., and Notholt, J.: Atmospheric hydrogen cyanide (HCN): Biomass burning source, ocean sink?, Geophys. Res. Lett., 27, 357-360, 2000 . 
Li, Q., Jacob, D. J., Yantosca, R. M., Heald, C. L., Singh, H. B., Koike, M., Zhao, Y., Sachse, G. W., and Streets, D. G.: A global three-dimensional model analysis of the atmospheric budgets of $\mathrm{HCN}$ and $\mathrm{CH}_{3} \mathrm{CN}$ : Constraints from aircraft and ground measurements, J. Geophys. Res.-Atmos., 108, 8827, https://doi.org/10.1029/2002JD003075, 2003.

Li, Q., Palmer, P. I., Pumphrey, H. C., Bernath, P., and Mahieu, E.: What drives the observed variability of $\mathrm{HCN}$ in the troposphere and lower stratosphere?, Atmos. Chem. Phys., 9, 85318543, https://doi.org/10.5194/acp-9-8531-2009, 2009.

Li, S.-M., Leithead, A., Moussa, S. G., Liggio, J., Moran, M. D., Wang, D., Hayden, K., Darlington, A., Gordon, M., Staebler, R., Makar, P. A., Stroud, C. A., McLaren, R., Liu, P. S. K., O’Brien, J., Mittermeier, R. L., Zhang, J., Marson, G., Cober, S. G., Wolde, M., and Wentzell, J. J. B.: Differences between measured and reported volatile organic compound emissions from oil sands facilities in Alberta, Canada, P. Natl. Acad. Sci. USA, 114, E3756E3765, 2017.

Liggio, J., Gordon, M., Smallwood, G., Li, S.-M., Stroud, C., Staebler, R., Lu, G., Lee, P., Taylor, B., and Brook, J. R.: Are emissions of black carbon from gasoline vehicles underestimated? Insights from near and on-road measurements, Environ. Sci. Technol., 46, 4819-4828, 2012.

Liggio, J., Moussa, S. G., Wentzell, J., Darlington, A., Liu, P., Leithead, A., Hayden, K., O’Brien, J., Mittermeier, R. L., Staebler, R., Wolde, M., and Li, S.-M.: Understanding the primary emissions and secondary formation of gaseous organic acids in the oil sands region of Alberta, Canada, Atmos. Chem. Phys., 17, 8411-8427, https://doi.org/10.5194/acp-17-8411-2017, 2017a.

Liggio, J., Stroud, C. A., Wentzell, J. J. B., Zhang, J., Sommers, J., Darlington, A., Liu, P. S. K., Moussa, S. G., Leithead, A., Hayden, K., Mittermeier, R. L., Staebler, R., Wolde, M., and Li, S. M.: Quantifying the primary emissions and photochemical formation of isocyanic acid downwind of oil sands operations, Environ. Sci. Technol., 51, 14462-14471, 2017b.

Link, M. F., Friedman, B., Fulgham, R., Brophy, P., Galang, A., Jathar, S. H., Veres, P., Roberts, J. M., and Farmer, D. K.: Photochemical processing of diesel fuel emissions as a large secondary source of isocyanic acid (HNCO), Geophys. Res. Lett., 43, 40334041, 2016.

Logue, B. A., Hinkens, D. M., Baskin, S. I., and Rockwood, G. A.: The analysis of cyanide and its breakdown products in biological samples, Crit. Rev. Anal. Chem., 40, 122-147, 2010.

Lough, G. C., Schauer, J. J., Lonneman, W. A., and Allen, M. K.: Summer and winter nonmethane hydrocarbon emissions from on-road motor vehicles in the Midwestern United States, J. Air Waste Manage. Assoc., 55, 629-646, 2005.

Matz, C. J., Stieb, D. M., and Brion, O.: Urban-rural differences in daily time-activity patterns, occupational activity and housing characteristics, Environ. Health, 14, 88, https://doi.org/10.1186/s12940-015-0075-y, 2015.

Mauderly, J. L. and Samet, J. M.: Is there evidence for synergy among air pollutants in causing health effects?, Environ. Health Perspect., 117, 1-6, 2009.

McCarter, J.: 2012 Annual Report, Offic of the Auditor General of Ontario, Ontario, Canada, 457 pp., 2012.

McDonald, B. C., Dallmann, T. R., Martin, E. W., and Harley, R. A.: Long-term trends in nitrogen oxide emissions from motor vehicles at national, state, and air basin scales, J. Geophys. Res.-
Atmos., 117, D00V18, https://doi.org/10.1029/2012JD018304, 2012.

McDonald, B. C., Gentner, D. R., Goldstein, A. H., and Harley, R. A.: Long-Term Trends in Motor Vehicle Emissions in U.S. Urban Areas, Environ. Sci. Technol., 47, 10022-10031, 2013.

Moussa, S. G., Leithead, A., Li, S.-M., Chan, T. W., Wentzell, J. J. B., Stroud, C., Zhang, J., Lee, P., Lu, G., Brook, J. R., Hayden, K., Narayan, J., and Liggio, J.: Emissions of hydrogen cyanide from on-road gasoline and diesel vehicles, Atmos. Environ., 131, 185-195, 2016.

Natural Resources Canada's Office of Energy Efficiency: Canadian Vehicle Survey: 2009 Summary Report, Natural Resources Canada, Ottawa, Canada, 72 pp., 2011.

Park, S. S., Kozawa, K., Fruin, S., Mara, S., Hsu, Y. K., Jakober, C., Winer, A., and Herner, J.: Emission factors for high-emitting vehicles based on on-road measurements of individual vehicle exhaust with a mobile measurement platform, J. Air Waste Manage. Assoc., 61, 1046-1056, 2011.

Parrish, D. D.: Critical evaluation of US on-road vehicle emission inventories, Atmos. Environ., 40, 2288-2300, 2006.

Pavlovic, R., Chen, J., Anderson, K., Moran, M. D., Beaulieu, P.A., Davignon, D., and Cousineau, S.: The FireWork air quality forecast system with near-real-time biomass burning emissions: Recent developments and evaluation of performance for the 2015 North American wildfire season, J. Air Waste Manage. Assoc., 66, 819-841, 2016.

Petzold, A., Ogren, J. A., Fiebig, M., Laj, P., Li, S.-M., Baltensperger, U., Holzer-Popp, T., Kinne, S., Pappalardo, G., Sugimoto, N., Wehrli, C., Wiedensohler, A., and Zhang, X.-Y.: Recommendations for reporting "black carbon" measurements, Atmos. Chem. Phys., 13, 8365-8379, https://doi.org/10.5194/acp13-8365-2013, 2013.

Pope, C. A. and Dockery, D. W.: Health effects of fine particulate air pollution: Lines that connect, J. Air Waste Manage. Assoc., 56, 709-742, 2006.

Rinsland, C. P., Dufour, G., Boone, C. D., Bernath, P. F., Chiou, L., Coheur, P.-F., Turquety, S., and Clerbaux, C.: Satellite boreal measurements over Alaska and Canada during JuneJuly 2004: Simultaneous measurements of upper tropospheric $\mathrm{CO}, \mathrm{C}_{2} \mathrm{H}_{6}, \mathrm{HCN}, \mathrm{CH}_{3} \mathrm{Cl}, \mathrm{CH}_{4}, \mathrm{C}_{2} \mathrm{H}_{2}, \mathrm{CH}_{3} \mathrm{OH}, \mathrm{HCOOH}, \mathrm{OCS}$, and $\mathrm{SF}_{6}$ mixing ratios, Global Biogeochem. Cy., 21, GB3008, https://doi.org/10.1029/2006gb002795, 2007.

Roberts, J. M., Veres, P. R., Cochran, A. K., Warneke, C., Burling, I. R., Yokelson, R. J., Lerner, B., Gilman, J. B., Kuster, W. C., Fall, R., and de Gouw, J.: Isocyanic acid in the atmosphere and its possible link to smoke-related health effects, P. Natl. Acad. Sci. USA, 108, 8966-8971, 2011.

Roberts, J. M., Veres, P. R., VandenBoer, T. C., Warneke, C., Graus, M., Williams, E. J., Lefer, B., Brock, C. A., Bahreini, R., Öztürk, F., Middlebrook, A. M., Wagner, N. L., Dubé, W. P., and de Gouw, J. A.: New insights into atmospheric sources and sinks of isocyanic acid, HNCO, from recent urban and regional observations, J. Geophys. Res.-Atmos., 119, 1060-1072, 2014.

Saliba, G., Saleh, R., Zhao, Y., Presto, A. A., Lambe, A. T., Frodin, B., Sardar, S., Maldonado, H., Maddox, C., May, A. A., Drozd, G. T., Goldstein, A. H., Russell, L. M., Hagen, F., and Robinson, A. L.: Comparison of gasoline direct-injection (GDI) and port fuel injection (PFI) vehicle emissions: Emission certification standards, cold-start, secondary organic aerosol formation 
potential, and potential climate impacts, Environ. Sci. Technol., 51, 6542-6552, 2017.

Sarkar, C., Sinha, V., Kumar, V., Rupakheti, M., Panday, A., Mahata, K. S., Rupakheti, D., Kathayat, B., and Lawrence, M. G.: Overview of VOC emissions and chemistry from PTR-TOFMS measurements during the SusKat-ABC campaign: high acetaldehyde, isoprene and isocyanic acid in wintertime air of the Kathmandu Valley, Atmos. Chem. Phys., 16, 3979-4003, https://doi.org/10.5194/acp-16-3979-2016, 2016.

Shim, C., Wang, Y., Singh, H. B., Blake, D. R., and Guenther, A. B.: Source characteristics of oxygenated volatile organic compounds and hydrogen cyanide, J. Geophys. Res.-Atmos., 112, D10305, https://doi.org/10.1029/2006JD007543, 2007.

Snelling, D. R., Smallwood, G. J., Liu, F., Gülder, Ö. L., and Bachalo, W. D.: A calibration-independent laser-induced incandescence technique for soot measurement by detecting absolute light intensity, Appl. Optics, 44, 6773-6785, 2005.

Statistics Canada: Road motor vehicle registrations, by type of vehicle, available at: http://www.statcan.gc.ca/ tables-tableaux/sum-som/101/cst01/trade14b-eng.htm (last access: 18 April 2018), 2016.

Stirn, R., Baquet, T. G., Kanjarkar, S., Meier, W., Geigle, K. P., Grotheer, H. H., Wahl, C., and Aigner, M.: Comparison of particle size measurements with laser-induced incandescence, mass spectroscopy, and scanning mobility particle sizing in a laminar premixed ethylene/air flame, Combust. Sci. Technol., 181, 329349, 2009.

Suarez-Bertoa, R. and Astorga, C.: Isocyanic acid and ammonia in vehicle emissions, Transp. Res. D, 49, 259-270, 2016.

Tan, Y., Lipsky, E. M., Saleh, R., Robinson, A. L., and Presto, A. A.: Characterizing the spatial variation of air pollutants and the contributions of high emitting vehicles in Pittsburgh, PA, Environ. Sci. Technol., 48, 14186-14194, 2014.

Urban, C. M. and Garbe, R. J.: Regulated and unregulated exhaust emissions from malfunctioning automobiles, SAE Tech. Pap. Ser., 790696, 7906, https://doi.org/10.4271/790696, 1979.

Urban, C. M. and Garbe, R. J.: Exhaust emissions form malfunctioning three-way catalyst-equipped automobiles, SAE Tech. Pap. Ser., 800511, 8005, https://doi.org/10.4271/800511, 1980.

US EPA - US Environmental Protection Agency: Toxicological review of hydrogen cyanide and cyanide salts, September 2010, US EPA, Washington, D.C., 153 pp., 2010.

Veres, P., Roberts, J. M., Warneke, C., Welsh-Bon, D., Zahniser, M., Herndon, S., Fall, R., and de Gouw, J.: Development of negativeion proton-transfer chemical-ionization mass spectrometry (NIPT-CIMS) for the measurement of gas-phase organic acids in the atmosphere, Int. J. Mass Spectrom., 274, 48-55, 2008.

Veres, P., Roberts, J. M., Burling, I. R., Warneke, C., de Gouw, J., and Yokelson, R. J.: Measurements of gas-phase inorganic and organic acids from biomass fires by negative-ion proton-transfer chemical-ionization mass spectrometry, J. Geophys. Res.Atmos., 115, D23302, https://doi.org/10.1029/2010JD014033, 2010.

Wang, J. M., Jeong, C.-H., Zimmerman, N., Healy, R. M., Wang, D. K., Ke, F., and Evans, G. J.: Plume-based analysis of vehicle fleet air pollutant emissions and the contribution from high emitters, Atmos. Meas. Tech., 8, 3263-3275, https://doi.org/10.5194/amt8-3263-2015, 2015.
Wang, Y., Xing, Z., Zhao, S., Zheng, M., Mu, C., and Du, K.: Are emissions of black carbon from gasoline vehicles overestimated? Real-time, in situ measurement of black carbon emission factors, Sci. Total Environ., 547, 422-428, 2016.

Wang, Z., Nicholls, S. J., Rodriguez, E. R., Kummu, O., Hörkkö, S., Barnard, J., Reynolds, W. F., Topol, E. J., DiDonato, A. J., and Hazen, S. L.: Protein carbamylation links inflammation, smoking,uremia and atherogenesis, Nat. Med., 13, 1176-1184, 2007.

Wentzell, J. J., Liggio, J., Li, S. M., Vlasenko, A., Staebler, R., Lu, G., Poitras, M. J., Chan, T., and Brook, J. R.: Measurements of gas phase acids in diesel exhaust: a relevant source of HNCO?, Environ. Sci. Technol., 47, 7663-7671, 2013.

Westerdahl, D., Wang, X., Pan, X., and Zhang, K. M.: Characterization of on-road vehicle emission factors and microenvironmental air quality in Beijing, China, Atmos. Environ., 43, 697-705, 2009.

Woodward-Massey, R., Taha, Y. M., Moussa, S. G., and Osthoff, H. D.: Comparison of negative-ion proton-transfer with iodide ion chemical ionization mass spectrometry for quantification of isocyanic acid in ambient air, Atmos. Environ., 98, 693-703, 2014.

Wu, J. S., Krishnan, S. S., and Faeth, G. M.: Refractive indices at visible wavelengths of soot emitted from buoyant turbulent diffusion flames, J. Heat Transfer, 119, 230-237, 1997.

Yli-Tuomi, T., Aarnio, P., Pirjola, L., Mäkelä, T., Hillamo, R., and Jantunen, M.: Emissions of fine particles, $\mathrm{NO}_{x}$, and $\mathrm{CO}$ from onroad vehicles in Finland, Atmos. Environ., 39, 6696-6706, 2005.

You, Y., Staebler, R. M., Moussa, S. G., Su, Y., Munoz, T., Stroud, C., Zhang, J., and Moran, M. D.: Long-path measurements of pollutants and micrometeorology over Highway 401 in Toronto, Atmos. Chem. Phys., 17, 14119-14143, https://doi.org/10.5194/acp-17-14119-2017, 2017.

Young, P. J., Emmons, L. K., Roberts, J. M., Lamarque, J.F., Wiedinmyer, C., Veres, P., and VandenBoer, T. C.: Isocyanic acid in a global chemistry transport model: Tropospheric distribution, budget, and identification of regions with potential health impacts, J. Geophys. Res.-Atmos., 117, D10308, https://doi.org/10.1029/2011JD017393, 2012.

Zavala, M., Herndon, S. C., Slott, R. S., Dunlea, E. J., Marr, L. C., Shorter, J. H., Zahniser, M., Knighton, W. B., Rogers, T. M., Kolb, C. E., Molina, L. T., and Molina, M. J.: Characterization of on-road vehicle emissions in the Mexico City Metropolitan Area using a mobile laboratory in chase and fleet average measurement modes during the MCMA-2003 field campaign, Atmos. Chem. Phys., 6, 5129-5142, https://doi.org/10.5194/acp-6-51292006, 2006.

Zavala, M., Herndon, S. C., Wood, E. C., Jayne, J. T., Nelson, D. D., Trimborn, A. M., Dunlea, E., Knighton, W. B., Mendoza, A., Allen, D. T., Kolb, C. E., Molina, M. J., and Molina, L. T.: Comparison of emissions from on-road sources using a mobile laboratory under various driving and operational sampling modes, Atmos. Chem. Phys., 9, 1-14, https://doi.org/10.5194/acp-9-12009, 2009.

Zhao, R., Lee, A. K. Y., Wentzell, J. J. B., McDonald, A. M., Toom-Sauntry, D., Leaitch, W. R., Modini, R. L., Corrigan, A. L., Russell, L. M., Noone, K. J., Schroder, J. C., Bertram, A. K., Hawkins, L. N., Abbatt, J. P. D., and Liggio, J.: Cloud partitioning of isocyanic acid (HNCO) and evidence of secondary source of HNCO in ambient air, Geophys. Res. Lett., 41, 6962-6969, 2014. 
Zhao, Y., Strong, K., Kondo, Y., Koike, M., Matsumi, Y., Irie, H., Rinsland, C. P., Jones, N. B., Suzuki, K., Nakajima, H., Nakane, $\mathrm{H}$., and Murata, I.: Spectroscopic measurements of tropospheric $\mathrm{CO}, \mathrm{C}_{2} \mathrm{H}_{6}, \mathrm{C}_{2} \mathrm{H}_{2}$ and $\mathrm{HCN}$ in northern Japan, J. Geophys. Res.-Atmos., 107, 4343, https://doi.org/10.1029/2001JD000748, 2002.
Zimmerman, N., Wang, J. M., Jeong, C. H., Ramos, M., Hilker, N., Healy, R. M., Sabaliauskas, K., Wallace, J. S., and Evans, G. J.: Field measurements of gasoline direct injection emission factors: Spatial and seasonal variability, Environ. Sci. Technol., 50, 2035-2043, 2016. 